\title{
Carbon dynamics and $\mathrm{CO}_{2}$ and $\mathrm{CH}_{4}$ outgassing in the Mekong delta
}

\author{
Alberto V. Borges ${ }^{1}$, Gwenaël Abril ${ }^{2,3}$, and Steven Bouillon ${ }^{4}$ \\ ${ }^{1}$ Chemical Oceanography Unit, University of Liège, 4000 Liège, Belgium \\ ${ }^{2}$ Programa de Geoquímica, Universidade Federal Fluminense, 24020015, Niterói, Brazil \\ ${ }^{3}$ Laboratoire Environnements et Paléoenvironnements Océaniques et Continentaux, CNRS, \\ Université de Bordeaux, 33405, Talence, France \\ ${ }^{4}$ Department of Earth and Environmental Sciences, KU Leuven, 3001 Leuven, Belgium
}

Correspondence: Alberto V. Borges (alberto.borges@ulg.ac.be)

Received: 20 October 2017 - Discussion started: 24 October 2017

Revised: 3 January 2018 - Accepted: 6 January 2018 - Published: 22 February 2018

\begin{abstract}
We report a data set of biogeochemical variables related to carbon cycling obtained in the three branches (My Tho, Hàm Luông, Cố Chiên) of the Mekong delta (Bến Tre province, Vietnam) in December 2003, April 2004, and October 2004. Both the inner estuary (upstream of the mouth) and the outer estuary (river plume) were sampled, as well as side channels. The values of the partial pressure of $\mathrm{CO}_{2}$ $\left(\mathrm{pCO}_{2}\right)$ ranged between 232 and $4085 \mathrm{ppm}, \mathrm{O}_{2}$ saturation level $\left(\% \mathrm{O}_{2}\right)$ between 63 and $114 \%$, and $\mathrm{CH}_{4}$ between 2 and $2217 \mathrm{nmol} \mathrm{L}^{-1}$, within the ranges of values previously reported in temperate and tropical meso- and macro-tidal estuaries. Strong seasonal variations were observed. In the upper oligohaline estuary, low $\mathrm{pCO}_{2}(479-753 \mathrm{ppm})$ and high $\% \mathrm{O}_{2}(98-106 \%)$ values were observed in April 2004 most probably related to freshwater phytoplankton growth owing to low freshwater discharge $\left(1400 \mathrm{~m}^{3} \mathrm{~s}^{-1}\right)$ and increase in water residence time; during the two other sampling periods with a higher freshwater discharge $\left(9300-17900 \mathrm{~m}^{3} \mathrm{~s}^{-1}\right)$, higher $\mathrm{pCO}_{2}(1895-2664 \mathrm{ppm})$ and lower $\% \mathrm{O}_{2}(69-84 \%)$ values were observed in the oligohaline part of the estuary. In October 2004, important phytoplankton growth occurred in the offshore part of the river plume as attested by changes in the contribution of particulate organic carbon (POC) to total suspended matter (TSM) (\%POC) and the stable isotope composition of POC $\left(\delta^{13} \mathrm{C}-\mathrm{POC}\right)$, possibly related to low TSM values (improvement of light conditions for phytoplankton development), leading to low $\mathrm{pCO}_{2}(232 \mathrm{ppm})$ and high $\% \mathrm{O}_{2}(114 \%)$ values. Water in the side channels in the Mekong delta was strongly impacted by inputs from the extensive shrimp farming ponds. The values of $\mathrm{pCO}_{2}$, $\mathrm{CH}_{4}, \% \mathrm{O}_{2}$, and the stable isotope composition of dissolved
\end{abstract}

inorganic carbon $\left(\delta^{13} \mathrm{C}\right.$-DIC) indicated intense organic matter degradation that was partly mediated by sulfate reduction in sediments, as revealed by the slope of total alkalinity (TA) and DIC covariations. The $\delta^{13} \mathrm{C}-\mathrm{POC}$ variations also indicated intense phytoplankton growth in the side channels, presumably due to nutrient enrichment related to the shrimp farming ponds. A data set in the mangrove creeks of the Ca Mau province (part of the Mekong delta) was also acquired in April and October 2004. These data extended the range of variability in $\mathrm{pCO}_{2}$ and $\% \mathrm{O}_{2}$ with more extreme values than in the Mekong delta (Bến Tre), with maxima and minima of $6912 \mathrm{ppm}$ and $37 \%$, respectively. Similarly, the maximum $\mathrm{CH}_{4}$ concentration $\left(686 \mathrm{nmol} \mathrm{L}^{-1}\right)$ was higher in the $\mathrm{Ca}$ Mau province mangrove creeks than in the Mekong delta (Bến Tre, maximum $222 \mathrm{nmol} \mathrm{L}^{-1}$ ) during the October 2004 cruise (rainy season and high freshwater discharge period). In April 2004 (dry season and low freshwater discharge period), the $\mathrm{CH}_{4}$ values were much lower than in October 2004 (average $19 \pm 13$ and $210 \pm 158 \mathrm{nmol} \mathrm{L}^{-1}$, respectively) in the Ca Mau province mangrove creeks, owing to the higher salinity (average $33.2 \pm 0.6$ and $14.1 \pm 1.2$, respectively) that probably led to higher sediment sulfate reduction, leading to inhibition of sediment methanogenesis and higher anaerobic $\mathrm{CH}_{4}$ oxidation. In the inner estuarine region (three branches of the Mekong delta), $\mathrm{CO}_{2}$ emissions to the atmosphere averaged $121 \mathrm{mmol} \mathrm{m}^{-2} \mathrm{~d}^{-1}$, and the $\mathrm{CH}_{4}$ emissions averaged $118 \mu \mathrm{mol} \mathrm{m}^{-2} \mathrm{~d}^{-1}$. The $\mathrm{CO}_{2}$ emission to the atmosphere from the Mekong inner estuary was higher than reported in the Yangtze and Pearl river inner estuaries. This was probably due to the lower salinity in the Mekong delta branches, possibly due to different morphology: rel- 
atively linear channels in the Mekong delta versus funnelshaped estuaries for the Yangtze and Pearl river inner estuaries.

\section{Introduction}

Estuaries are the main pathways for the transfer of particulate and dissolved matter from land to the ocean (through rivers). Particulate and dissolved matter undergo strong transformations, as estuaries are sites of intense biogeochemical processing (for example Bianchi, 2006) that in most cases leads to substantial emissions of greenhouse gases such as carbon dioxide $\left(\mathrm{CO}_{2}\right)$ and methane $\left(\mathrm{CH}_{4}\right)$ (for example Borges and Abril, 2011). Most estuarine environments are net heterotrophic ecosystems (Gattuso et al., 1998; Testa et al., 2012), leading to the production and emission to the atmosphere of $\mathrm{CO}_{2}$ and $\mathrm{CH}_{4}$. The production of $\mathrm{CO}_{2}$ and $\mathrm{CH}_{4}$ is modulated by various physical features resulting from estuarine geomorphology such as water residence time (Borges et al., 2006; Joesoef et al., 2017), tidal amplitude and vertical stratification (Borges, 2005; Koné et al., 2009; Crosswell et al., 2012; Joesoef et al., 2015), and connectivity with tidal flats and salt marshes (Middelburg et al., 2002; Cai, 2011). Highly eutrophic (Cotovicz Jr. et al., 2015) or strongly stratified estuarine systems (Koné et al., 2009) can exceptionally act as sinks of $\mathrm{CO}_{2}$ due to high carbon sequestration, although high organic matter sedimentation can concomitantly lead to high $\mathrm{CH}_{4}$ production and emission to the atmosphere (Koné et al., 2010; Borges and Abril, 2011).

The global $\mathrm{CO}_{2}$ emissions from estuaries have been estimated by several studies (Abril and Borges, 2004; Borges, 2005; Borges et al., 2005; Chen and Borges, 2009; Laruelle et al., 2010, 2013; Cai, 2011; Chen et al., 2012, 2013) and range from 0.1 to $0.6 \mathrm{PgC} \mathrm{yr}^{-1}$, equivalent in magnitude to $5-30 \%$ of the oceanic $\mathrm{CO}_{2}$ sink of $\sim 2 \mathrm{PgC} \mathrm{yr}^{-1}$ (Le Quéré et al., 2016). These values were derived from the scaling of air-water $\mathrm{CO}_{2}$ flux intensities (per surface area) compiled from published data that were extrapolated to estimates of the global surface of estuaries. The most recent estimates are lower than the older ones, reflecting the increase by an order of magnitude in the availability of data on air-water $\mathrm{CO}_{2}$ fluxes and more precise estimates of surface areas of estuaries structured by types (for example Dürr et al., 2011). The global estimates of $\mathrm{CH}_{4}$ emissions from estuaries are also relatively variable, ranging between 1 and $7 \mathrm{TgCH}_{4} \mathrm{yr}^{-1}$ (Bange et al., 1994; Upstill-Goddard et al., 2000; Middelburg et al., 2002; Borges and Abril, 2011) and are modest compared to other natural $\left(220-350 \mathrm{TgCH}_{4} \mathrm{yr}^{-1}\right)$ and anthropogenic $\left(330-335 \mathrm{TgCH}_{4} \mathrm{yr}^{-1}\right) \mathrm{CH}_{4}$ emissions (Kirschke et al., 2013). Unlike $\mathrm{CO}_{2}$, the most recent global estimate of estuarine $\mathrm{CH}_{4}$ emissions is the highest because it accounts for the direct emissions of $\mathrm{CH}_{4}$ from sediment to atmosphere (when intertidal areas are exposed) (Borges and Abril, 2011). However, published estuarine $\mathrm{CH}_{4}$ emissions are most probably underestimated because they do not account for $\mathrm{CH}_{4}$ ebullition and gas flaring, although emissions to the atmosphere of $\mathrm{CH}_{4}$ originating from gassy sediments in coastal environments have been shown to be intense (Borges et al., 2016, 2017). Reported $\mathrm{CO}_{2}$ and $\mathrm{CH}_{4}$ emissions from rivers are also highly uncertain and the proposed values also span a considerable range. Global riverine $\mathrm{CO}_{2}$ emission estimates range between $0.1 \mathrm{PgC} \mathrm{yr}^{-1}$ (Liu et al., 2010) and 1.8 $\mathrm{PgC} \mathrm{yr}^{-1}$ (Raymond et al., 2013), while riverine $\mathrm{CH}_{4}$ emission estimates range between $2 \mathrm{TgCH}_{4} \mathrm{yr}^{-1}$ (Bastviken et al., 2011) and $27 \mathrm{TgCH}_{4} \mathrm{yr}^{-1}$ (Stanley et al., 2016). Both $\mathrm{CO}_{2}$ and $\mathrm{CH}_{4}$ riverine emissions mainly occur in tropical areas (Borges et al., 2015a, b).

The first studies of $\mathrm{CO}_{2}$ and $\mathrm{CH}_{4}$ dynamics and emissions from estuaries were carried out during the late 1990s in Europe (Frankignoulle et al., 1996, 1998; Middelburg et al., 2002) and the US (Cai and Wang, 1998). Since then, $\mathrm{CO}_{2}$ data coverage has tremendously increased with additional studies at subtropical and tropical latitudes (for example Sarma et al., 2012; Chen et al., 2012; Rao and Sarma, 2016) and in the large river-estuarine systems such as the Amazon (Lefèvre et al., 2017), the Mississippi (Huang et al., 2015), the Yangtze (Changjiang) (Zhai et al., 2007; Zhang et al., 2008), and the Pearl (Guo et al., 2009; Zhou et al., 2009). The number of studies on $\mathrm{CH}_{4}$ in estuarine and coastal environments has not increased in recent years as spectacularly as those concerning $\mathrm{CO}_{2}$, attracting less research efforts because the marine source of $\mathrm{CH}_{4}$ to the atmosphere (0.4-1.8 $\mathrm{TgCH}_{4} \mathrm{yr}^{-1}$; Bates et al., 1996; Rhee et al., 2009) is very modest compared to other natural and anthropogenic $\mathrm{CH}_{4}$ emissions (Kirschke et al., 2013); however, continental shelves and estuaries are more intense sources of $\mathrm{CH}_{4}$ to the atmosphere than the open ocean, in particular shallow and permanently well-mixed coastal zones (Borges et al., 2016, 2017). However, numerous large river-estuarine systems, such as the Mekong although it is the world's 10th largest river in water discharge $\left(470 \mathrm{~km}^{3} \mathrm{yr}^{-1}\right), 12 \mathrm{th}$ largest in length $(4800 \mathrm{~km})$, and 21st largest in drainage area $\left(795000 \mathrm{~km}^{2}\right)$ (Li and Bush, 2015), remain totally uncharted with respect to $\mathrm{CO}_{2}$ and $\mathrm{CH}_{4}$ data.

As a contribution to the special issue in Biogeosciences on "Human impacts on carbon fluxes in Asian river systems", we report a data set obtained in the three branches (Mỹ Tho, Hàm Luông, Cố Chiên) of the Mekong delta (Fig. 1) in December 2003, April 2004, and October 2004 of biogeochemical variables related to carbon cycling: $\mathrm{pH}$, total alkalinity (TA), $\mathrm{O}_{2}$, calculated partial pressure of $\mathrm{CO}_{2}$ $\left(\mathrm{pCO}_{2}\right)$, dissolved $\mathrm{CH}_{4}$ concentration, particulate $(\mathrm{POC})$ and dissolved (DOC) organic carbon concentration and stable isotopic composition, particulate nitrogen $(\mathrm{PN})$, dissolved inorganic carbon (DIC) stable isotopic composition, and total suspended matter (TSM). The aim of the paper is to give a general description of carbon cycling with an emphasis on 

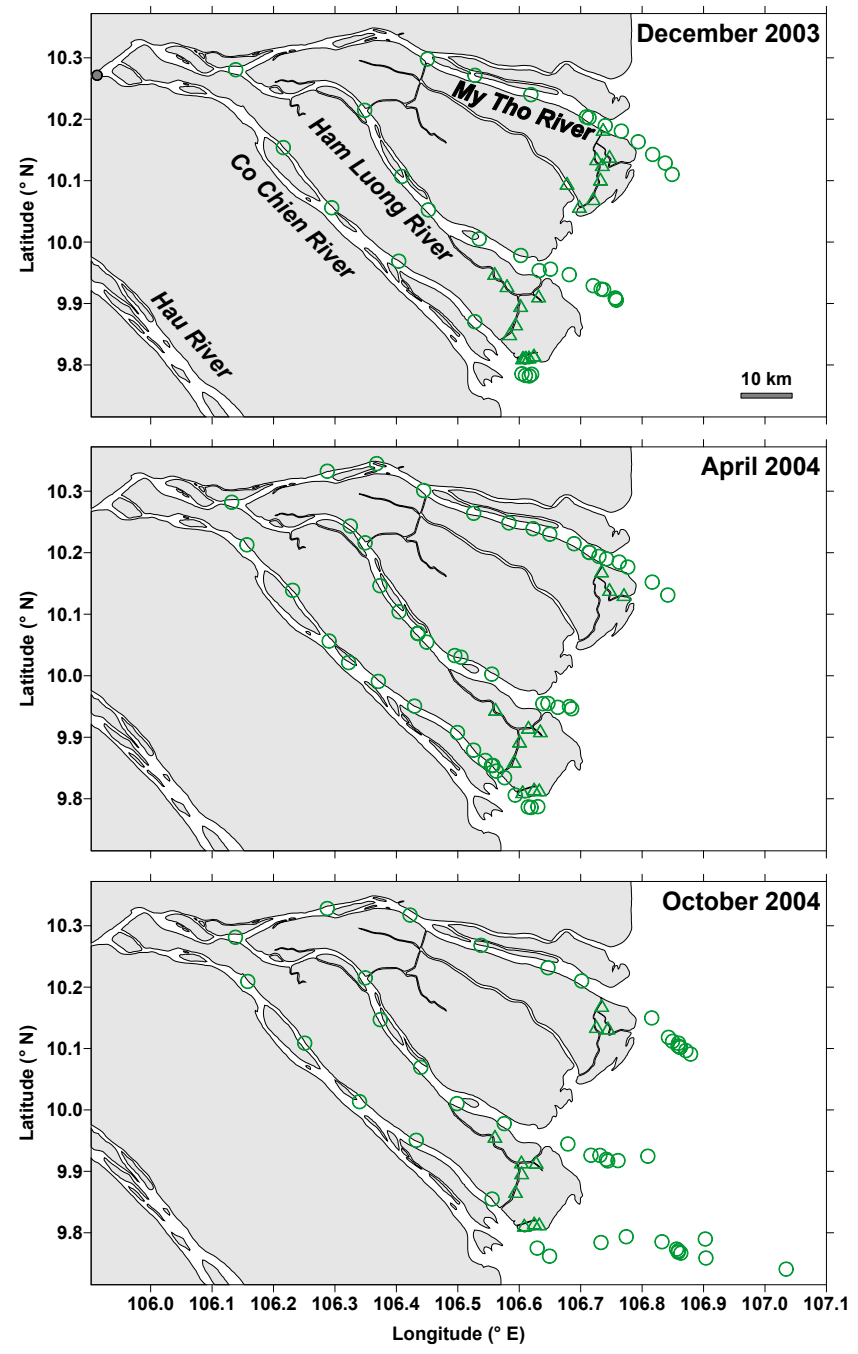

Figure 1. Map of sampling stations in December 2003, April 2004, and October 2004 in the three inner estuarine branches of the Mekong delta (circles) (Mỹ Tho, Hàm Luông, and Cố Chiên) and side channels (triangles). The small grey dot indicates the location of the bridge across the river at the city of Vĩnh Long from which the distance downstream is calculated in Fig. 3.

$\mathrm{CO}_{2}$ and $\mathrm{CH}_{4}$ dynamics in the Mekong delta estuarine system that can be used as a reference state to evaluate future changes in response to modifications in hydrology related the construction of planned large dams (leading to water abstraction and sediment retention), eutrophication, shoreline erosion, and sea level rise.

\section{Material and methods}

\subsection{Description of the Mekong River and delta}

Himalayan rivers (Yangtze, Mekong, Salween, Ayeyarwady, Ganges, Brahmaputra, Indus) are among the world's largest. The Mekong River is one of the longest rivers among the Himalayan watersheds, ranking it as the 12th longest river in the world. It flows $4800 \mathrm{~km}$ from the eastern part of the Tibetan Plateau through six different countries (China, Myanmar, Lao People's Democratic Republic (PDR), Thailand, Cambodia, Vietnam), into the South China Sea, draining an area of $795000 \mathrm{~km}^{2}$. The basin is divided into the Upper Mekong (parts of China and Myanmar, surface of $195000 \mathrm{~km}^{2}$, first $2000 \mathrm{~km}$ in length) and the Lower Mekong (parts of Lao PDR, Thailand, Cambodia, and Vietnam; surface of $600000 \mathrm{~km}^{2}$ ). The Upper Mekong is mountainous (altitude 400-5000 m) with no significant large tributaries and a low population density $\left(<10\right.$ inhabitants $\left.\mathrm{km}^{-2}\right)$. The Lower Mekong is lowland, drains very large tributary river systems, and is densely populated (80-460 inhabitants $\mathrm{km}^{-2}$ ). Climate ranges from cold temperate in the Upper Mekong to tropical monsoonal in the Lower Mekong. The annual flow of the Mekong River is $\sim 470 \mathrm{~km}^{3}$, ranking 10th among the world's largest rivers (Dai and Trenberth, 2002). Water sources are snowmelt in the Upper Mekong and surface run-off in the Lower Mekong. Seasonal variations in freshwater flow are controlled by the East Asian monsoons, resulting in an annual unimodal flood pulse. About $75 \%$ of the annual flow occurs in 4 months (July-October). The delta is divided into two main rivers, the Hâu and the Tiền, which equally share the total freshwater discharge. The Tiền River further divides into the Mỹ Tho, Hàm Luông, and Cố Chiên river branches (Fig. 1), which deliver 8, 14, and 23\%, respectively, of total freshwater from the Mekong network (based on the average of five different estimates reported by Nguyen et al., 2008). The annual sediment load was $\sim 130$ 160 million tons in the 1960s and 110 million tons in the 1990s according to Milliman and Farnsworth (2011). Li and Bush (2015) report a less dramatic decrease in annual sediment load from 171 million tons for the pre-regulated period (1923-1991) to 168 million tons for the regulated period (1992-2007). Estimates of the annual solute transport range between 40 and 123 million tons (Meybeck and Carbonnel, 1975; Gaillardet et al., 1999; Li and Bush, 2015). Exposed lithological strata are dominated by shales $(43.2 \%)$, followed by carbonates $(21.4 \%)$, shield rocks $(18.2 \%)$, sands and sandstone $(8.4 \%)$, basalts $(5.8 \%)$, and acid volcanic rocks (2.9\%) (Amiotte Suchet et al., 2003). The Mekong River basin is populated by 70 million people and this population is expected to increase to 100 million by 2050 (Varis et al., 2012). Recent and fast economic development has substantially increased the use of water resources (Piman et al., 2013), in particular for agriculture, energy (hydropower), and fishery (Västilä et al., 2010). Until recently, the Mekong 
River was considered one of the last unregulated great rivers with a flow regime close to its natural state (Adamson et al., 2009). Economic development in the region has led to the construction of several dams mainly for the production of hydropower, potentially affecting water and sediment flows (Fu et al., 2008; Wang et al., 2011; Lu et al., 2014; Piman et al., 2013, 2016). The construction of major infrastructures is planned on the transboundary Srepok, Tônle San, and Srekong rivers, which contribute up to $20 \%$ of the total annual water flow of the Mekong (Piman et al., 2016).

The Mekong River delta covers an area of $50000 \mathrm{~km}^{2}$ and is the third-largest tide-dominated delta in the world after the Amazon and Ganges-Brahmaputra deltas. The upper limit of the delta (limit of the tidal influence) is the city of Phnom Penh in Cambodia, and at the coast it extends in the north from the mouth of the Saigon River to Cape Ca Mau in the south. The delta is meso-tidal with an average tidal amplitude of $2.5 \mathrm{~m}$ at the estuarine mouths and a maximum tidal amplitude of $3.8 \mathrm{~m}$, and tides have mixed diurnal and semi-diurnal components, with a dominance of the semi-diurnal (period $\sim 12 \mathrm{~h}$ ) component (Takagi et al., 2016). It is tremendously important in the food supply and economic activity of Vietnam, as it sustains $90 \%$ of rice (> 20 million tons annually) and $60 \%$ of national seafood production. The development of shrimp farming in the delta has led to the reduction of mangrove forests (de Graaf and Xuan, 1998; Nguyen et al., 2011), which today only remain significantly in the Ca Mau province. Shrimp farming started in the late 1970s and has accelerated during the mid-1980s until present (de Graaf and Xuan, 1998; Tong et al., 2010). The delta is populated by more than 17 million people ( $>80 \%$ in rural areas), representing nearly a quarter of Vietnam's total population, with an annual population growth of more than $2 \%$. The delta is a low-lying area with an average elevation of $<2$ m a.s.l., making it one of the most vulnerable deltas in the world to sea level rise (IPCC, 2014). The decrease in freshwater and sediment delivery combined with the rising sea level and subsidence, as well as coastal (shoreline) erosion, are potential threats for economic activities in the Mekong delta, for instance due to the impact of salinity intrusion on agriculture, compromising the economy and livelihood of local populations (Smajgl et al., 2015). Several studies predict that a large fraction (70-95\%) of the sediment load could be trapped by hydropower reservoirs if all of the planned infrastructures are effectively built (Kummu et al., 2010; Kondolf et al., 2014). In addition, sediment river delivery could also vary in response to changes in climate (Västilä et al., 2010; Lauri et al., 2012; Darby et al., 2016). This would have important consequences on the sediment deposition in the delta that seems to have already shifted from a net depositional (accretion) regime into a net erosion regime (Anthony et al., 2015; Liu et al., 2017). The nutrient inputs to the continental shelf from the Mekong delta sustain high phytoplankton growth in the Mekong River plume (Grosse et al., 2010), which is one the most productive areas of the South China Sea (Liu et al., 2002; Qiu et al., 2011; Gao et al., 2013; Loisel et al., 2017).

\subsection{Sampling}

Sampling in three branches of the Mekong delta (My Tho, Hàm Luông, Cố Chiên; Fig. 1) was carried out during three field campaigns (29 November-5 December 2003; $2-$ 7 April 2004; 14-19 October 2004) on the inspection boat of the Bến Tre Fishery Department, in collaboration with the Research Institute for Aquaculture No. 2 (Ho Chi Minh City). Sampling in the mangrove creeks of the $\mathrm{Ca} \mathrm{Mau}$ province was carried out during two field campaigns (1014 April 2004; 23-25 October 2004) with a speed boat. The map of the sampling stations in the mangrove creeks of the Ca Mau province is given by Koné and Borges (2008), who reported $\mathrm{pCO}_{2}, \% \mathrm{O}_{2}$, and TSM data.

Samples for $\mathrm{pH}, \mathrm{TA}, \mathrm{O}_{2}$, TSM, POC and $\delta^{13} \mathrm{C}-\mathrm{POC}, \mathrm{PN}$, $\delta^{13} \mathrm{C}$-DIC were collected and analysed at all stations of all three field campaigns. Samples for dissolved $\mathrm{CH}_{4}$ concentration were collected during the two last field campaigns, for DOC during the last field campaign, and for dissolved silica (DSi) during the second field campaign.

\subsection{Sample collection and analysis}

Salinity and water temperature were measured in situ using a portable thermosalinometer (WTW Cond 340) with a precision of \pm 0.1 and $\pm 0.1^{\circ} \mathrm{C}$, respectively. Subsurface waters (top $1 \mathrm{~m}$ ) were sampled with a $1.7 \mathrm{~L}$ Niskin bottle (General Oceanics) for the determination of $\mathrm{pH}$ and dissolved gases sampled with a silicone tube. Water for the determination of $\mathrm{O}_{2}$ was sampled in a Winkler-type borosilicate bottle and the oxygen saturation level $\left(\% \mathrm{O}_{2}\right)$ was measured immediately after collection with a polarographic electrode (WTW Oxi 340) calibrated on saturated air, with an accuracy of $\pm 0.1 \%$. The $\mathrm{pH}$ was also sampled in a Winkler bottle and measured immediately after collection with a combination electrode (Metrohm 6.0232.100) calibrated on the US National Bureau of Standards scale as described by Frankignoulle and Borges (2001), with a precision and estimated accuracy of \pm 0.001 and $\pm 0.005 \mathrm{pH}$ units, respectively. Water for the determination of $\mathrm{CH}_{4}$ was sampled in duplicate with a silicone tube from the $1.7 \mathrm{~L}$ Niskin bottle into $50 \mathrm{~mL}$ borosilicate serum bottles, allowing the flushing of 2-3 times the final volume; then the water was poisoned with $100 \mu \mathrm{L}$ of a saturated solution of $\mathrm{HgCl}_{2}$ sealed with a butyl stopper and crimped with an aluminium cap. The $\mathrm{CH}_{4}$ concentration was measured using the headspace technique (Weiss, 1981) using a gas chromatograph with flame ionization detection (Hewlett Packard 5890A), calibrated with certified $\mathrm{CH}_{4}: \mathrm{N}_{2}$ mixtures of 10 and $200 \mathrm{ppm} \mathrm{CH}_{4}$ (Air Liquide, France), with a precision of $\pm 5 \%$. Water for the analysis of $\delta^{13} \mathrm{C}$-DIC was sampled in $12 \mathrm{~mL}$ Exetainer vials and poisoned with $20 \mu \mathrm{L}$ of a saturated $\mathrm{HgCl}_{2}$ solution. A He headspace was created, 
and $\sim 300 \mu \mathrm{L}$ of $\mathrm{H}_{3} \mathrm{PO}_{4}$ was added to convert all DIC species to $\mathrm{CO}_{2}$. After overnight equilibration part of the headspace was injected into the He stream of an elemental analyser isotope ratio mass spectrometer (EA-IRMS; Thermo Finnigan Flash1112 and Thermo Finnigan Delta+XL) for $\delta^{13} \mathrm{C}$ measurements, with a precision of better than $\pm 0.2 \%$.

Samples for TSM were filtered on pre-weighed and precombusted $\left(5 \mathrm{~h}\right.$ at $\left.450^{\circ} \mathrm{C}\right) 47 \mathrm{~mm}$ Whatman $\mathrm{GF} / \mathrm{F}$ filters $(0.7 \mu \mathrm{m}$ porosity), rinsed with bottled drinking water to avoid salt contributions and subsequently dried. Samples for POC, $\mathrm{PN}$, and $\delta^{13} \mathrm{C}$-POC were filtered on pre-combusted $25 \mathrm{~mm}$ Whatman GF/F filters ( $0.7 \mu \mathrm{m}$ porosity) and dried. These filters were later decarbonated with $\mathrm{HCl}$ fumes under partial vacuum for $4 \mathrm{~h}$, re-dried, and packed in Ag cups. POC and PN were determined on a Thermo Finnigan Flash EA1112 using acetanilide as a standard, and the resulting $\mathrm{CO}_{2}$ was measured on a Thermo Finnigan delta $+\mathrm{XL}$ interfaced via a ConFlo III to the EA. Reproducibility of $\delta^{13} \mathrm{C}$-POC measurements was better than $\pm 0.2 \%$. Samples for DOC and $\delta^{13} \mathrm{C}$-DOC, TA, DSi, and major cations $\left(\mathrm{Ca}^{2+}, \mathrm{Mg}^{2+}, \mathrm{Na}^{+}\right.$, $\mathrm{K}^{+}$) were obtained by pre-filtering water on cellulose acetate filters for DSi, and pre-combusted Whatman GF/F filters for the other variables, followed by filtration on $0.2 \mu \mathrm{m}$ cellulose acetate syringe filters (Sartorius). DOC and $\delta^{13} \mathrm{C}$-DOC were stored in $40 \mathrm{~mL}$ borosilicate bottles and preserved by addition of $50 \mu \mathrm{L}$ of $\mathrm{H}_{3} \mathrm{PO}_{4}$. DSi and major cations were stored in $20 \mathrm{~mL}$ high-density polyethylene scintillation vials and preserved with $\mathrm{HNO}_{3}(50 \mu \mathrm{L}$ from $\mathrm{DSi}, 10 \mu \mathrm{L}$ for major cations). TA was stored un-poisoned in $100 \mathrm{~mL}$ polyethylene vials. DOC concentrations and $\delta^{13} \mathrm{C}$ signatures were measured with a modified Thermo HiPerTOC TOC analyser and interfaced with a Thermo delta + XL IRMS as described by Bouillon et al. (2006). DSi was measured with the colorimetric method of Koroleff (1983), with a precision of $\pm 0.1 \mu \mathrm{mol} \mathrm{L}{ }^{-1}$. TA was measured in $50 \mathrm{~mL}$ samples using automated Gran titration with $0.1 \mathrm{M} \mathrm{HCl}$ as titrant, with a reproducibility of $\pm 1 \mu \mathrm{mol} \mathrm{kg}{ }^{-1}$. Samples for major cations were measured with inductively coupled plasmaatomic emission spectrometry (ICP-AES) and with a reproducibility better than $\pm 3 \%$.

The dissolved concentration of $\mathrm{CO}_{2}$ is expressed as $\mathrm{pCO}_{2}$ in parts per million (ppm), following Henry's law (Henry, 1803). Measurements of TA and $\mathrm{pH}$ were used to compute $\mathrm{pCO}_{2}$ and DIC using the carbonic acid thermodynamic dissociation constants of Cai and Wang (1998), with an estimated accuracy of $\pm 5 \%$ and $\pm 5 \mu \mathrm{mol} \mathrm{kg}-1$, respectively (Frankignoulle and Borges, 2001). Measured TA and pH values were well within the range of applicability of the $\mathrm{pCO}_{2}$ calculation according to Abril et al. (2015), with $\mathrm{pH}>7$ and $\mathrm{TA}>1000 \mu \mathrm{mol} \mathrm{kg}{ }^{-1}$, even in freshwaters.

Air-water fluxes of $\mathrm{CO}_{2}\left(\mathrm{FCO}_{2}\right)$ and $\mathrm{CH}_{4}\left(\mathrm{FCH}_{4}\right)$ were calculated according to

$F=k \cdot \Delta G$ where $F$ is the flux of the gas, $\Delta G$ is the air-water gradient of the gas, and $k$ is the gas transfer velocity.

Values of $k$ were computed using wind speed field measurements with a handheld anemometer, and the parameterization as a function of wind speed given by Raymond and Cole (2001) (the "non-dome" parameterization). The $k$ values in estuarine environments are highly variable and parameterizations as a function of wind speed are site-specific due to variable contribution of fetch limitation and tidal currents (Borges et al., 2004). The parameterization of Raymond and Cole (2001) probably provides minimal $k$ values; thus, the $\mathrm{FCO}_{2}$ and $F \mathrm{CH}_{4}$ values given hereafter are considered conservative estimates. Atmospheric $\mathrm{pCO}_{2}$ values were retrieved from the National Oceanic and Atmospheric Administration Earth System Research Laboratory atmospheric measurement network database at the Guam station (Mariana Islands, $13.386^{\circ} \mathrm{N} 144.656^{\circ} \mathrm{E}$ ) located in the Pacific Ocean, approximately at the same latitude as the Mekong delta. The atmospheric $\mathrm{pCO}_{2}$ values were converted from dry air to humid air using the water vapour formulation as a function of salinity and temperature given by Weiss and Price (1980). For the three sampling periods, the dry air $\mathrm{CO}_{2}$ mixing ratio averaged $376 \pm 4 \mathrm{ppm}$ and the humid air $\mathrm{CO}_{2}$ mixing ratio averaged $362 \pm 3 \mathrm{ppm}$. For $\mathrm{CH}_{4}$, a constant atmospheric value of $1.8 \mathrm{ppm}$ was used. The Henry constant of $\mathrm{CO}_{2}$ and $\mathrm{CH}_{4}$ was computed from salinity and temperature according to Weiss (1974) and Yamamoto et al. (1976), respectively, and the Schmidt number for $\mathrm{CO}_{2}$ and $\mathrm{CH}_{4}$ was computed from temperature according to Wanninkhof (1992). The airwater $\mathrm{CO}_{2}$ and $\mathrm{CH}_{4}$ values were area-averaged and scaled to the surface of the three estuarine branches using surface areas derived from satellite images from Google Earth.

\subsection{Mixing models}

Mixing models were used to investigate sources and sinks of TA, DIC, $\mathrm{O}_{2}$, and $\delta^{13} \mathrm{C}$-DIC along the salinity gradient. We used a mixing model for TA, DIC, and $\mathrm{O}_{2}$ that assumes a conservative mixing and no gaseous exchange with the atmosphere for a solute $(E)$ according to

$E_{\mathrm{S}}=\left(\frac{E_{\mathrm{M}}-E_{\mathrm{F}}}{\mathrm{Sal}_{\mathrm{M}}-\mathrm{Sal}_{\mathrm{F}}}\right) \mathrm{Sal}+E_{\mathrm{f}}$,

where $E_{\mathrm{S}}$ is the concentration of $E$ at a given salinity (Sal), $E_{\mathrm{F}}$ is the concentration of $E$ at the freshwater end-member (with a salinity of $\mathrm{Sal}_{\mathrm{F}}$ ), and $E_{\mathrm{M}}$ is the concentration of $E$ at the marine end-member (with a salinity of $S_{\mathrm{M}}$ ). 


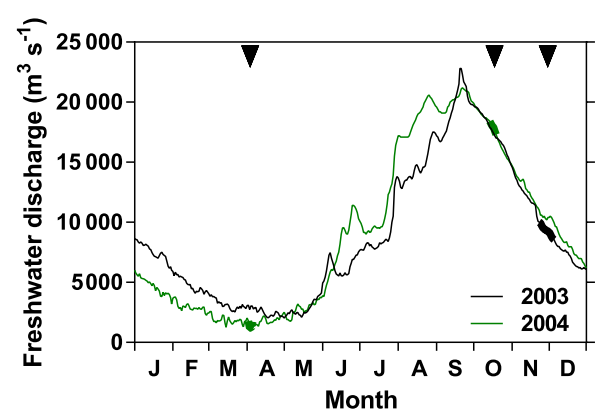

Figure 2. Seasonal evolution of daily freshwater discharge in the Mekong River at Tân Châu in 2003 and 2004. Thick lines and black triangles indicate the three sampling periods.

The conservative mixing of $\delta^{13} \mathrm{C}$-DIC was computed according to Mook and Tan (1991):

$$
\begin{gathered}
\delta^{13} \mathrm{C}-\mathrm{DIC}=\left(\operatorname{Sal}\left(\mathrm{DIC}_{\mathrm{F}} \delta^{13} \mathrm{C}-\mathrm{DIC}_{\mathrm{F}}-\mathrm{DIC}_{\mathrm{M}} \delta^{13} \mathrm{C}-\mathrm{DIC}_{\mathrm{M}}\right)\right. \\
\left.+\mathrm{Sal}_{\mathrm{F}} \mathrm{DIC} \mathrm{M}_{\mathrm{M}} \delta^{13} \mathrm{C}-\mathrm{DIC}_{\mathrm{M}}-\mathrm{Sal}_{\mathrm{M}} \mathrm{DIC}_{\mathrm{F}} \delta^{13} \mathrm{C}-\mathrm{DIC}_{\mathrm{F}}\right) / \\
\left.\left(\mathrm{Sal}_{(\mathrm{DIC}}-\mathrm{DIC}_{\mathrm{M}}\right)+\mathrm{Sal}_{\mathrm{F}} \mathrm{DIC} \mathrm{M}-\mathrm{Sal}_{\mathrm{M}} \mathrm{DIC} C_{\mathrm{F}}\right),
\end{gathered}
$$

where Sal is the salinity of the sample, DIC $\mathrm{F}_{\mathrm{F}}$ and $\delta^{13} \mathrm{C}_{\mathrm{F}}$-DIC are, respectively, the DIC concentration and stable isotope composition at the freshwater end-member, and $\mathrm{DIC}_{\mathrm{M}}$ and ${ }^{13 \mathrm{C}} \mathrm{C}_{\mathrm{M}}$-DIC are, respectively, the DIC concentration and stable isotope composition at the marine end-member.

\subsection{Data set}

The geo-referenced and time-stamped data set is available in the Supplement of the paper (Table S1).

\section{Results and discussion}

\subsection{Spatial and seasonal variations in the main branches of the Mekong delta (M ̃̃ Tho, Hàm Luông, Cố Chiên)}

The three sampling cruises covered three distinct phases of the hydrological cycle (Fig. 2): low water (April 2004), close to high water (October 2004), and falling water (December 2003). This strongly affected the salinity intrusion into the three inner estuarine channels (Mỹ Tho, Hàm Luông, Cố Chiên): in December 2003 and October 2004, freshwater was observed throughout the inner estuarine channels down to the mouths, while in April 2004 the salinity intrusion occurred up to $60 \mathrm{~km}$ upstream of the estuarine mouths (Fig. 3). The $\mathrm{pCO}_{2}$ values showed a general inverse pattern compared to salinity and strongly decreased offshore from the mouth of the three delta arms in December 2003 and October 2004, while the decreasing pattern of $\mathrm{pCO}_{2}$ occurred within the three estuarine channels in April 2004. In December 2003 and October 2004, the $\mathrm{pCO}_{2}$ values upstream (freshwater) ranged between 1895 and 2664 ppm, well above atmospheric equilibrium ( $362 \mathrm{ppm}$ ) and above the range of values (703-1597 ppm) reported by Alin et al. (2011) in the upstream reaches of the Mekong river network during the high water period (September-October 2004-2005). This difference might be due to a stronger human influence on the densely populated Mekong delta, or to geomorphology (lowland rivers versus higher-altitude rivers). The $\mathrm{pCO}_{2}$ values from the extensive data set in the Mekong River at Tân Châu ( $\sim 100 \mathrm{~km}$ upstream of the area we sampled) ranged between 390 and $4861 \mathrm{ppm}$ and averaged $1325 \mathrm{ppm}$ (Li et al., 2013), encompassing the $\mathrm{pCO}_{2}$ values we obtained in the freshwater part of the delta. The $\mathrm{pCO}_{2}$ values in five streams of the Red River network in northern Vietnam ranged between 750 and $2400 \mathrm{ppm}$ and averaged $1597 \mathrm{ppm}$ (Le et al., 2017), comparable to the $\mathrm{pCO}_{2}$ values we obtained in the freshwater part of the Mekong delta. The $\mathrm{pCO}_{2}$ values in freshwaters were significantly correlated to $\% \mathrm{O}_{2}$ (Fig. 4) indicating biological control of both these variables. Similarly, the correlation between $\mathrm{pCO}_{2}$ and $\delta^{13} \mathrm{C}$-DIC (Fig. 4) resulted from the degradation of organic matter that leads to a preferential release of ${ }^{12} \mathrm{CO}_{2}$ (since organic matter is isotopically light compared to the background DIC pool), leading to more negative $\delta^{13} \mathrm{C}$-DIC values. The high $\mathrm{pCO}_{2}$ values in freshwaters in December 2003 and October 2004 corresponded to low $\% \mathrm{O}_{2}$ values (69-84\%) indicative of degradation of organic matter. In April 2004, the most upstream sampled stations of the delta (freshwater) were characterized by $\mathrm{pCO}_{2}$ values (479-753 ppm) closer to atmospheric equilibrium and high $\% \mathrm{O}_{2}$ values $(98-106 \%)$ indicative of freshwater phytoplankton development during low water, probably related to an increase in water residence time related to low freshwater discharge (Reynolds and Descy, 1996), as also observed in other tropical rivers (for example Descy et al., 2017). Phytoplankton development during low water was also reported in the Upper Mekong River (confluence with the Tonle Sap River) by Ellis et al. (2012), based on elemental and lignin analyses. The impact of biological activity on $\mathrm{CO}_{2}$ dynamics in the uppermost freshwater part of the estuary was confirmed by $\delta^{13} \mathrm{C}$-DIC values that were higher in April $2004(-8.7 \pm 0.4 \%, n=5)$ compared to December $2003(-10.6 \pm 0.6, n=6 \%)$ and October 2004 $(-10.9 \pm 0.3 \%, n=15)$. Indeed, $\mathrm{pCO}_{2}$ was positively related to freshwater discharge, while $\% \mathrm{O}_{2}$ and $\delta^{13} \mathrm{C}$-DIC were negatively related to freshwater discharge (Fig. 5), as also shown in other tropical rivers such as the Oubangui (Bouillon et al., 2012b, 2014). The data set in the Mekong River at Tân Châu reported by Li et al. (2013) shows a similar seasonal pattern, with lower $\mathrm{pCO}_{2}$ values during low water (March-May) and higher $\mathrm{pCO}_{2}$ values during high water (October-December). In April 2004, there was a marked increase in $\mathrm{pCO}_{2}$ from the most upstream stations (salinity 0 ) to the stations located at $60 \mathrm{~km}$ from Vĩnh Long (corresponding roughly to a salinity of 2). This increase in $\mathrm{pCO}_{2}$ was mirrored by a general decrease in $\% \mathrm{O}_{2}$, suggesting en- 

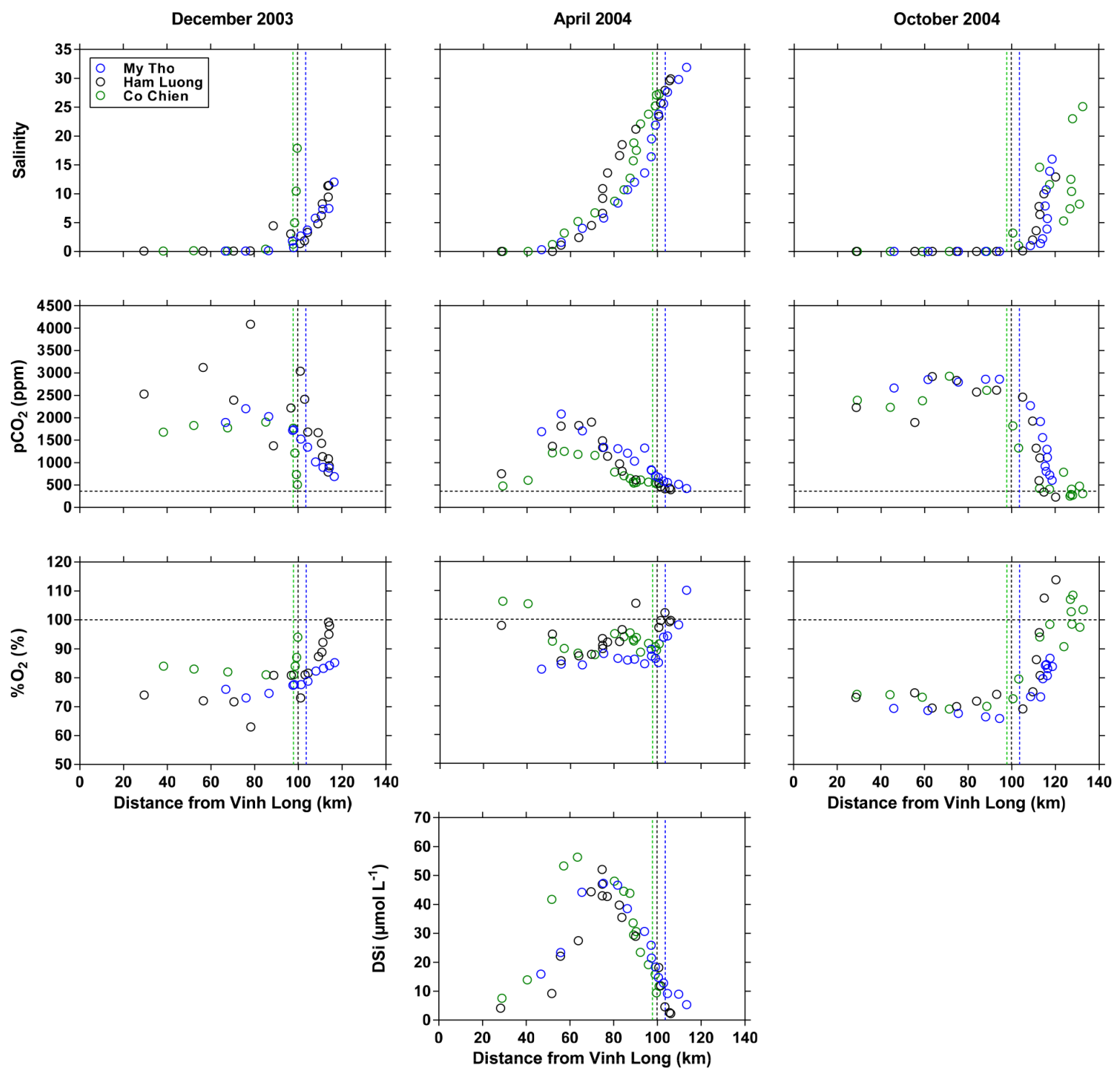

Figure 3. Distribution as a function of distance downstream of the city of Vĩnh Long of salinity, partial pressure of $\mathrm{CO}_{2}\left(\mathrm{pCO}_{2}, \mathrm{ppm}\right.$, oxygen saturation level $\left(\% \mathrm{O}_{2}, \%\right)$, and dissolved silica $\left(\mathrm{DSi}, \mu \mathrm{mol} \mathrm{L} \mathrm{L}^{-1}\right)$ in the three branches of the Mekong delta (Mỹ Tho, Hàm Luông, and Cố Chiên) in December 2003, April 2004, and October 2004. The vertical dotted lines indicate the location of the river mouths.

hanced organic matter degradation in the oligohaline estuarine region, typical of estuarine environments (for example Morris et al., 1978; Bianchi, 2006). In parallel, there was a general increase in DSi from salinity 0 to 2 suggesting that part of the enhanced organic matter degradation in the upper estuary in April 2004 was fuelled by the decay of freshwater diatoms due to haline (osmotic) stress (for example Muylaert and Sabbe, 1999; Ragueneau et al., 2002), as also observed in other tropical estuaries such as the Tana and the Kidogoweni in Kenya (Bouillon et al., 2007a, b). In December 2003 and April 2004, a general gradual increase in $\mathrm{pCO}_{2}$ was also observed along the estuarine channels towards the mouth, although the $\% \mathrm{O}_{2}$ decrease was less marked than in April 2004. The TA values at zero salin- ity ranged from $\sim 960$ to $\sim 980 \mu \mathrm{mol} \mathrm{kg}-1$ in October 2004 and December 2003, respectively, significantly lower than in April $2004\left(\sim 1400 \mu \mathrm{mol} \mathrm{kg}^{-1}\right)$ (Mann-Whitney (MW) test at 0.05 level, $p<0.0001)$. These values are higher than the $\mathrm{HCO}_{3}^{-}$concentration of $949 \mu \mathrm{mol} \mathrm{kg}{ }^{-1}$ reported by Meybeck and Carbonnel (1975) at Phnom Penh from January 1961 to 1962. The data of Meybeck and Carbonnel (1975) were obtained about $230 \mathrm{~km}$ upstream of our sampling sites in the Mekong delta; thus, the difference could be due to the general downstream increase in dissolved ions typically observed in rivers (for example Whitton, 1975), but we cannot exclude methodological differences or long-term changes. $\mathrm{Li}$ and Bush (2015) did not identify clear long-term trends in $\mathrm{HCO}_{3}^{-}$at two stations in the Lower Mekong River from 
1960 to 2011. Our TA values converge with the median $\left(1082 \mu \mathrm{mol} \mathrm{kg}^{-1}\right)$ of a large data set during the 1972-1996 period from 42 stations in the Lower Mekong delta compiled by the Mekong River Commission and reported by $\mathrm{Li}$ et al. (2014) and the average of TA $\left(1026 \mu \mathrm{mol} \mathrm{kg}{ }^{-1}\right)$ reported by Huang et al. (2017). The seasonal variations in TA follow those of freshwater discharge (Fig. 5), as also shown in other major rivers such as the Mississippi (Cai et al., 2008) and the Oubangui (Bouillon et al., 2012b, 2014). TA in freshwater was correlated to $\mathrm{Ca}^{2+}$ with a slope of 2.0 (Fig. S1 in the Supplement) consistent with the weathering of calcite $\left(\mathrm{CaCO}_{3}, \mathrm{HCO}_{3}^{-}: \mathrm{Ca}^{2+}=2: 1\right)$ and to $\mathrm{Mg}^{2+}$ with a slope of 2.2 consistent with the weathering of dolomite $((\mathrm{Ca}$, $\left.\mathrm{Mg}) \mathrm{CO}_{3}, \mathrm{HCO}_{3}^{-}:\left(\mathrm{Ca}^{2+}, \mathrm{Mg}^{2+}\right)=2: 1\right)$. Such stoichiometric ratios between $\mathrm{HCO}_{3}^{-}$and $\mathrm{Ca}^{2+}$ and $\mathrm{Mg}^{2+}$ might also result from weathering of silicate rocks such as anorthite (Caplagioclase feldspar, $\mathrm{CaAl}_{2} \mathrm{Si}_{2} \mathrm{O}_{8}, \mathrm{HCO}_{3}^{-}: \mathrm{Ca}^{2+}=2: 1$ ), chlorite $\left(\mathrm{Mg}_{5} \mathrm{Al}_{2} \mathrm{Si}_{3} \mathrm{O}_{10}, \mathrm{HCO}_{3}^{-}: \mathrm{Mg}^{2+}=2: 1\right)$, or olivine $\left(\mathrm{MgSiO}_{4}, \mathrm{HCO}_{3}^{-}: \mathrm{Mg}^{2+}=2: 1\right)$. However, Li et al. (2014) have shown, based on an extensive water chemistry data set, that carbonate rock weathering largely dominates silicate weathering in the Lower Mekong River, and this seems to also be the case in the Upper Mekong River (Manaka et al., 2015). TA in freshwater was also correlated to $\mathrm{Na}^{+}$but with a slope of 0.5 , lower than expected from the weathering of albite $\left(\mathrm{NaAlSi}_{3} \mathrm{O}_{8} ; \mathrm{HCO}_{3}^{-}: \mathrm{Na}^{+}=1: 1\right)$, and to $\mathrm{K}^{+}$but with a slope of 14, higher than expected from the weathering of microcline (K-feldspar, $\mathrm{KAlSi}_{3} \mathrm{O}_{8}, \mathrm{HCO}_{3}^{-}: \mathrm{K}^{+}=1: 1$ ). Weathering of calcite alone would not account for all of the TA, but this would be the case for a mixture of weathering of calcite and dolomite (Fig. S2), also in agreement with the analysis of Li et al. (2014).

As a function of salinity, $\mathrm{pCO}_{2}$ and $\% \mathrm{O}_{2}$ showed regular decreasing and increasing patterns, respectively, in the three delta channels (Fig. 6). The lowest offshore $\mathrm{pCO}_{2}$ value was observed in October 2004 (314 ppm at 27.0 salinity), lower than in December 2003 (509 ppm at 17.9 salinity) and April 2004 (423 ppm at 31.9 salinity). TA showed a linear evolution against salinity, indicative of nearconservative mixing behaviour. This was consistent with a near-conservative mixing behaviour of major cations $\mathrm{Ca}^{2+}$, $\mathrm{Mg}^{2+}, \mathrm{K}^{+}, \mathrm{Na}^{+}$) (Fig. S3). DIC generally followed the seasonal and spatial patterns of those of TA. $\delta^{13} \mathrm{C}$-DIC showed a typical increasing pattern with salinity (Mook and Tan 1991; Bouillon et al., 2012a), resulting from the mixing of freshwater with more negative $\delta^{13} \mathrm{C}$ signatures $(-14$ to $-8 \%$ ) and marine water with a $\delta^{13} \mathrm{C}$ signature close to $0 \%$. The ${ }^{13} \mathrm{C}$ depleted signature in freshwater DIC results mainly from the degradation of organic matter, which contributes $\mathrm{CO}_{2}$ with a signature close to that of the source organic carbon, which in the Mekong delta for POC ranged between -28 and $-26 \%$, and from the weathering of carbonate and silicate minerals (which are typically driven by reaction with $\mathrm{CO}_{2}$ derived from organic matter). $\mathrm{CH}_{4}$ showed very strong seasonal variations in freshwaters of the Mekong delta with
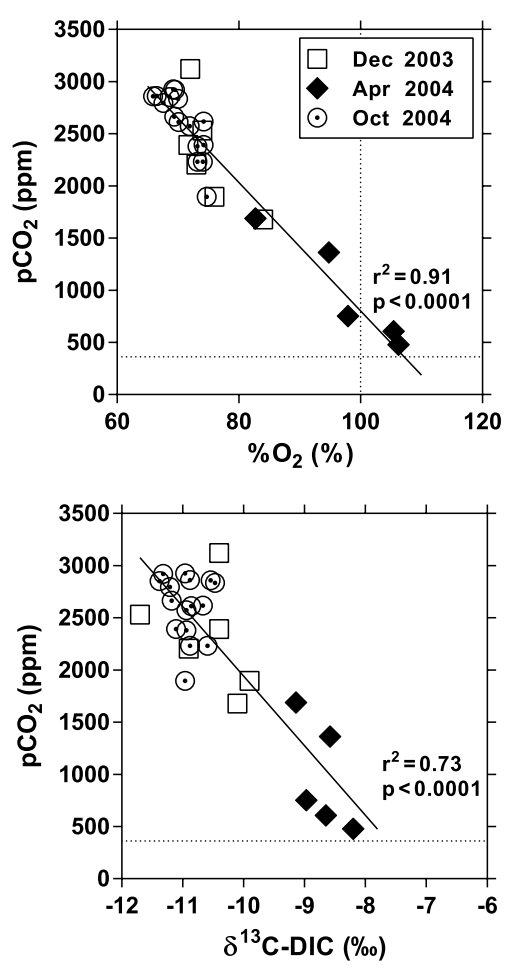

Figure 4. Variation in the partial pressure of $\mathrm{CO}_{2}\left(\mathrm{pCO}_{2}, \mathrm{ppm}\right)$ as a function of oxygen saturation level $\left(\% \mathrm{O}_{2}, \%\right)$ and stable isotope composition of dissolved inorganic carbon $\left(\delta^{13} \mathrm{C}\right.$-DIC, \%o) in the freshwaters (salinity 0) of the three branches of the Mekong delta (Mỹ Tho, Hàm Luông, and Cố Chiên) in December 2003, April 2004, and October 2004. The vertical dotted line indicates $\mathrm{O}_{2}$ saturation $(100 \%)$; the horizontal line indicates the average atmospheric $\mathrm{pCO}_{2}$ value.

values $<20 \mathrm{nmol} \mathrm{L}^{-1}$ in April 2004 and values ranging between 25 and $220 \mathrm{nmol} \mathrm{L}^{-1}$ in October 2004 (significantly different, MW test $p<0.0001$ ). The seasonal $\mathrm{CH}_{4}$ variation could result from the flooding of riparian and floodplain areas and/or $\mathrm{CH}_{4}$ inputs from surface run-off during the rainy season and high water period leading to high $\mathrm{CH}_{4}$ values in October 2004. The downstream decrease in $\mathrm{CH}_{4}$ in the estuarine salinity mixing zone is typical (Borges and Abril, 2011; Upstill-Goddard and Barnes, 2016), resulting from $\mathrm{CH}_{4}$ riverine loss in the estuary due to emission to the atmosphere, microbial $\mathrm{CH}_{4}$ oxidation, and mixing with marine waters that have $\mathrm{CH}_{4}$ concentrations close to atmospheric equilibrium (Rhee et al., 2009). The $\mathrm{CH}_{4}$ concentration in the most offshore sampled station was indeed close to atmospheric equilibrium in April $2004\left(2 \mathrm{nmol} \mathrm{L}^{-1}\right)$ for a salinity of 31.9 but was higher in October $2004\left(17 \mathrm{nmol} \mathrm{L}^{-1}\right)$, reflecting the lower salinity of 17.0. These values encompassed the $\mathrm{CH}_{4}$ concentrations of $4-6 \mathrm{nmol} \mathrm{L}^{-1}$ reported by Tseng et al. (2017) $150 \mathrm{~km}$ offshore from the Mekong delta river mouth. 

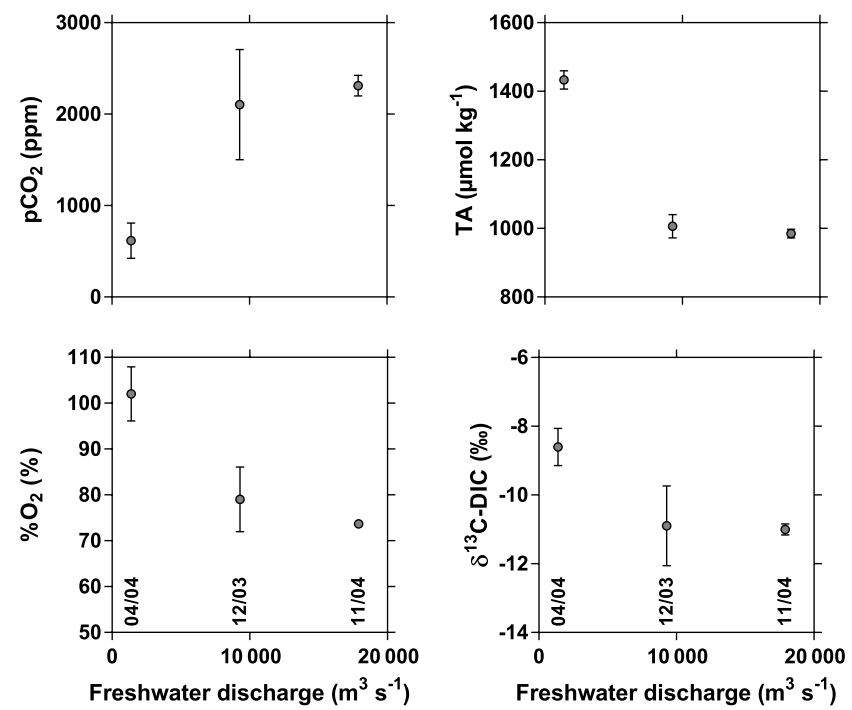

Figure 5. Variation as a function of freshwater discharge $\left(\mathrm{m}^{3} \mathrm{~s}^{-1}\right)$ of the partial pressure of $\mathrm{CO}_{2}\left(\mathrm{pCO}_{2}, \mathrm{ppm}\right)$, oxygen saturation level $\left(\% \mathrm{O}_{2}, \%\right)$, total alkalinity (TA, $\left.\mu \mathrm{mol} \mathrm{kg}{ }^{-1}\right)$, and stable isotope composition of dissolved inorganic carbon $\left(\delta^{13} \mathrm{C}\right.$-DIC, $\%$ o $)$ in the freshwaters (salinity 0 ) of the three branches of the Mekong delta (My Tho, Hàm Luông, and Cố Chiên) in December 2003, April 2004, and October 2004. Sampling dates (mm/yy) are indicated in the bottom panels.

TSM values showed marked spatial gradients in October 2004 with high values up to $447 \mathrm{mg} \mathrm{L}^{-1}$ in freshwaters and low values $\left(2 \mathrm{mg} \mathrm{L}^{-1}\right)$ in marine waters. In April 2004 and December 2003, TSM values in freshwaters were significantly lower (MW test, $p<0.0001$ ) and the spatial variations along the salinity gradient were less obvious. POC concentration ranged between 0.2 and $4.0 \mathrm{mg} \mathrm{L}^{-1}$, and the seasonal and spatial variations in POC were very similar to those in TSM. \%POC values ranged between 2 and $4 \%$, typical for the corresponding range of TSM values in world rivers (Meybeck, 1982; Ludwig et al., 1996) and in estuaries (Abril et al., 2002) and within the range measured in the Lower Mekong just upstream of the confluence with the Tonle Sap river during an annual cycle by Ellis et al. (2012). However, \%POC values were distinctly higher (up to $\sim 13 \%$ ) in marine waters in October 2004, probably resulting from a phytoplankton bloom, as also testified by low POC: PN ratios (as low as 4.9 ), high $\% \mathrm{O}_{2}$ (up to $114 \%$ ) and $\delta^{13} \mathrm{C}$ DIC (up to $0 \%$ ) values, and low $\mathrm{pCO}_{2}$ (as low as $232 \mathrm{ppm}$ at salinity 12.9) values. The phytoplankton bloom probably resulted from higher light availability in marine waters owing to lower TSM values (down to $2 \mathrm{mg} \mathrm{L}^{-1}$ ). Reported seasonal cycles of remotely sensed chlorophyll $a$ concentration also indicate higher phytoplankton biomass and primary production in October compared to April and December (Gao et al., 2013; Loisel et al., 2017). The $\delta^{13} \mathrm{C}$-POC values in the freshwater part of the delta (salinity $<1$ ) from the three sampling campaigns averaged $-26.7 \pm 0.7 \%$ o $(n=34)$, distinctly higher than the data from Ellis et al. (2012), which averaged $-29.8 \pm 0.9 \%$, but similar to data collected by Martin et al. (2013; average $-26.4 \%$ ) at the same site as the Ellis et al. (2012) study. These $\delta^{13} \mathrm{C}$-POC values are consistent with the expected dominance of terrestrial $\mathrm{C} 3$ vegetation in the riverine organic carbon load.

In October 2004, DOC showed a decreasing pattern while $\delta^{13} \mathrm{C}$-DOC values increased, as typically observed in estuaries (Bouillon et al., 2012a). Within the freshwater zone (salinity $<1)$, DOC values $\left(2.4 \pm 0.2 \mathrm{mg} \mathrm{L}^{-1}, n=19\right)$ were within the range $\left(0.9-5.1 \mathrm{mg} \mathrm{L}^{-1}\right)$ reported by Huang et al. (2017), and $\delta^{13} \mathrm{C}$-DOC values $(-27.8 \pm 0.6 \%, n=19)$ were again consistent with a dominance of terrestrial C3 vegetation inputs and close to values reported by Martin et al. (2013) slightly upstream in the Lower Mekong. The $\delta^{13} \mathrm{C}$ values were significantly lower in DOC than POC for the same samples in October 2004 (Fig. 7) (Wilcoxon matchedpair test at the 0.05 level, $p<0.0001$ ), probably reflecting the more refractory nature of riverine DOC compared to POC, the latter being removed faster during estuarine mixing and gradually replaced by POC of phytoplankton origin with a higher $\delta^{13} \mathrm{C}$ value.

\subsection{Distinct patterns in side channels compared to the main branches of the Mekong delta}

The sampled biogeochemical variables showed distinct patterns in the side channels of the Mekong delta compared to the main channels (Mỹ Tho, Hàm Luông, and Cố Chiên), irrespective of the sampling period. The observed patterns are consistent with the influence from the very extensive ponds devoted to shrimp farming that border the side channels of the Mekong delta (Tong et al., 2010). TSM, POC, and \%POC values were generally higher in the side channels than in the three main estuarine channels. In December 2003, TSM and POC were statistically higher in the side channels than in the three main channels (MW test $p=0.0273$ and $p<0.0001$, respectively) but not for the other two cruises, although the statistical comparisons were probably obscured by the mixing-induced changes along the salinity gradient. The DOC concentrations from the October 2004 cruise were also higher in the side channels (MW test $p=0.0267$ ). Higher \%POC values could indicate a higher contribution of phytoplankton biomass to TSM, and this is consistent with the $\delta^{13} \mathrm{C}$-POC values that were about 5-6\%o lower than the values in the three main estuarine channels at the same salinity values. There is an isotopic fractionation by phytoplanktonic primary production of about $20 \%$ o during DIC uptake (Hellings et al., 1999), corresponding roughly to the difference in $\delta^{13} \mathrm{C}$ values between POC (overall average: $-27.4 \pm 1.8 \%$ ) and DIC (overall average: $-8.2 \pm 2.4 \%$ ) in the side channels. The phytoplankton primary production was probably sustained by high inorganic nutrient inputs from shrimp farming ponds typically observed in adja- 

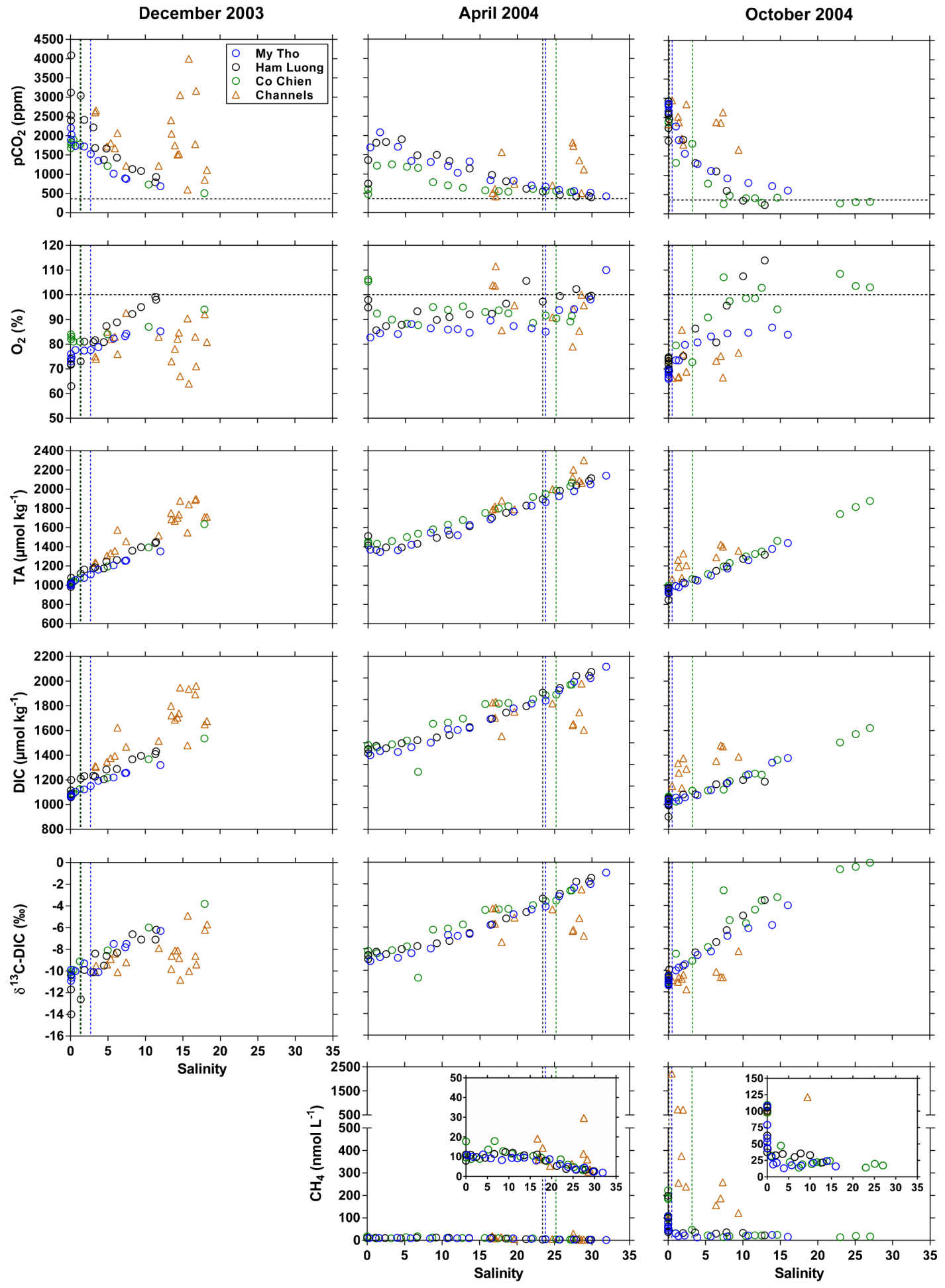

Figure 6. 

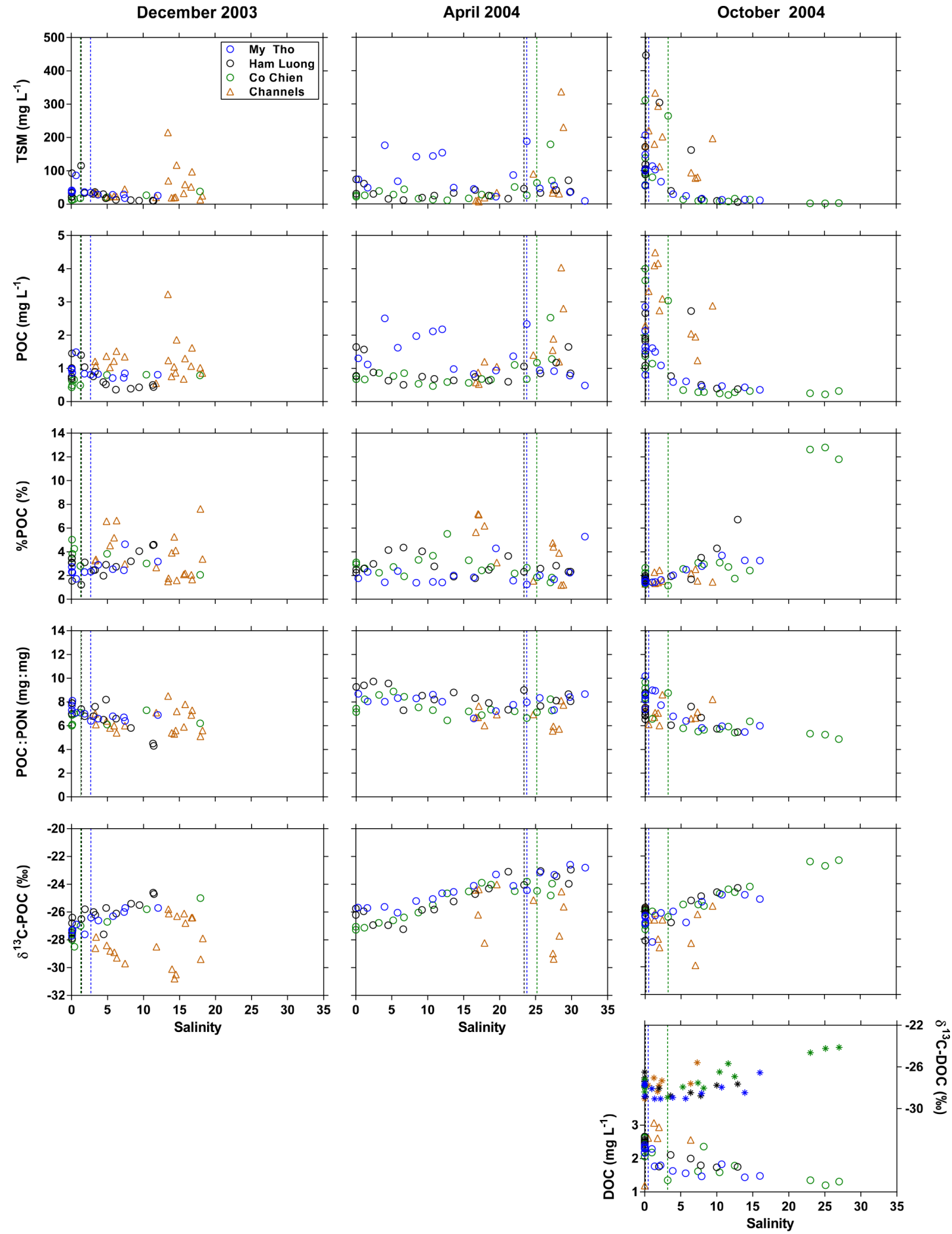

Figure 6. Distribution as a function of salinity of the partial pressure of $\mathrm{CO}_{2}\left(\mathrm{pCO}_{2}, \mathrm{ppm}\right)$, oxygen saturation level $\left(\% \mathrm{O}_{2}, \%\right)$, total alkalinity (TA, $\mu \mathrm{mol} \mathrm{kg}{ }^{-1}$ ), dissolved inorganic carbon (DIC, $\left.\mu \mathrm{mol} \mathrm{kg}-1\right)$, stable isotope composition of DIC $\left(\delta^{13} \mathrm{C}-\mathrm{DIC}, \%\right.$ ), dissolved $\mathrm{CH}_{4}$ concentration $\left(\mathrm{nmol} \mathrm{L}^{-1}\right)$, total suspended matter $\left(\mathrm{TSM}, \mathrm{mg} \mathrm{L}^{-1}\right)$, particulate organic carbon (POC, $\mathrm{mg} \mathrm{L}^{-1}$ ), percent of POC in TSM $(\% \mathrm{POC}$, $\%$ ), POC-to-particulate nitrogen ratio (POC: $\mathrm{PN}, \mathrm{mg}: \mathrm{mg})$, stable isotope composition of POC ( $\delta^{13} \mathrm{C}-\mathrm{POC}, \%$ ), dissolved organic carbon (DOC, $\left.\mathrm{mg} \mathrm{L}^{-1}\right)$, and stable isotope composition of DOC $\left(\delta^{13} \mathrm{C}-\mathrm{DOC}, \%\right.$ ) in the three branches of the Mekong delta (Mỹ Tho, Hàm Luông, and Cố Chiên) and side channels in December 2003, April 2004, and October 2004. The vertical dotted lines indicate the location of the river mouths. Horizontal dotted lines indicate the $\mathrm{CO}_{2}$ and $\mathrm{O}_{2}$ atmospheric equilibrium. 


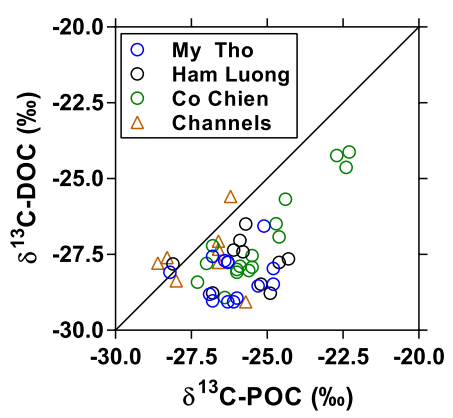

Figure 7. Stable isotope composition of dissolved organic carbon $\left(\delta^{13} \mathrm{C}\right.$-DOC, $\%$ ) as a function of the stable isotope composition of particulate organic carbon $\left(\delta^{13} \mathrm{C}\right.$-POC, $\%$ ) in the three branches of the Mekong delta (Mỹ Tho, Hàm Luông, and Cố Chiên) and side channels in October 2004. The solid line indicates the 1:1 line.

cent channels (for example Cardozo and Odebrecht, 2014) or within the ponds themselves (Alongi et al., 1999a). However, the more negative $\delta^{13} \mathrm{C}$-DIC values in the side channels indicate sustained $\mathrm{CO}_{2}$ production from organic matter degradation related to the shrimp ponds (Alongi et al., 2000) (MW test $p=0.0253$ in December 2003 and $p=0.0040$ in April 2004). This is consistent with generally higher $\mathrm{pCO}_{2}$ values and lower $\% \mathrm{O}_{2}$ in the side channels compared to the adjacent estuarine channels. As for TSM and POC, $\mathrm{pCO}_{2}$ and $\% \mathrm{O}_{2}$ were only statistically different between side and main channels in December 2013 (MW test $p<0.0001$ for both), as the statistical comparisons were probably obscured by the mixing-induced changes along the salinity gradient. Although there was indication of phytoplankton development based on $\delta^{13} \mathrm{C}$-POC (see above), the overall system was net heterotrophic, leading to accumulation of $\mathrm{CO}_{2}, \mathrm{CH}_{4}$, and light DIC and a decrease in $\mathrm{O}_{2}$. The distinctly higher $\mathrm{CH}_{4}$ values in side channels compared to main estuarine channels would indicate that part of the organic matter degradation in the side channels occurs in sediments (MW test $p=0.0369$ in April 2004 and $p<0.0001$ in October 2004). Alongi et al. (1999b) showed that methanogenesis in the sediments of shrimp farming ponds is low in the $\mathrm{Ca}$ Mau province. This allows us to suggest that the high $\mathrm{CH}_{4}$ in the side channels were presumably coming from the side channel sediments and not from the shrimp farming ponds. The generally higher TA values in the side channels than in estuarine channels could also indicate the effect of diagenetic anaerobic processes (for example Borges et al., 2003) (MW test $p<0.0001$ in December 2003 and October 2004).

We further explored data using the difference (or anomaly) between observed data and data predicted from conservative mixing models, noted as $\Delta$ (Fig. 8). Negative $\Delta \delta^{13} \mathrm{C}$-DIC values were correlated to those of $\Delta \mathrm{O}_{2}$ and $\Delta \mathrm{DIC}$, in particular in the side channels, as expected from production of $\mathrm{CO}_{2}$ and consumption of $\mathrm{O}_{2}$ due to degradation of organic matter. In October 2004, distinct positive $\Delta \delta^{13} \mathrm{C}$-DIC val- ues were associated with positive $\Delta \mathrm{O}_{2}$ and negative $\Delta$ DIC in the Hàm Luông and Cố Chiên resulting from high phytoplankton production in the most offshore waters, as mentioned in the previous section. The relation between positive $\Delta \mathrm{DIC}$ and negative $\Delta \mathrm{O}_{2}$ in the side channels also indicates degradation of organic matter, while negative $\triangle \mathrm{DIC}$ and positive $\Delta \mathrm{O}_{2}$ in October 2004 in the Hàm Luông and Cố Chiên confirm the occurrence of high phytoplankton production in the most offshore waters. The slope of the linear regression of $\triangle D I C$ as a function of $\Delta \mathrm{O}_{2}$ in the side channels ranged from 3.4 to 4.4 . These values are distinctly higher than those expected from the degradation of organic matter following the Redfield stoichiometry $\left(\Delta \mathrm{DIC}: \Delta \mathrm{O}_{2}=106: 138=0.8\right)$. The slope of the relation between $\triangle \mathrm{DIC}$ and $\Delta \mathrm{O}_{2}$ in October 2004 in the Hàm Luông and Cố Chiên (1.4) was lower than in the side channels but still higher than that predicted from Redfield stoichiometry. One possible explanation is that the change of concentration due to the exchange of gases with the atmosphere (equilibration) is faster for $\mathrm{O}_{2}$ than $\mathrm{CO}_{2}$ due to the effect on the latter of the buffer capacity of seawater. Another explanation that could explain the distinctly higher $\Delta$ DIC : $\Delta \mathrm{O}_{2}$ ratio in the side channels relates to anaerobic organic matter degradation in sediments that seems higher compared to estuarine channels as also suggested by higher $\mathrm{CH}_{4}$ concentrations. The relative change of TA and DIC can be used to identify the processes involved in the generation of these quantities (for example Borges et al., 2003). The theoretical relative change of $\Delta \mathrm{TA}$ versus $\triangle \mathrm{DIC}$ was derived from the stoichiometry of biogeochemical reactions, based on Brewer and Goldman (1976) for aerobic respiration, on Smith and Key (1975) for $\mathrm{CaCO}_{3}$ dissolution, and on Froelich et al. (1979) for anaerobic reactions. The slope of the linear regression of $\triangle \mathrm{TA}$ versus $\triangle \mathrm{DIC}$ ranged between 0.55 and 0.87 . Such values might have resulted from a combination of aerobic organic matter degradation $(\triangle \mathrm{TA}: \triangle \mathrm{DIC}=-0.2)$ and dissolution of $\mathrm{CaCO}_{3}$ (or $\left.\mathrm{CaMg}\left(\mathrm{CO}_{3}\right)_{2}\right)(\Delta \mathrm{TA}: \Delta \mathrm{DIC}=2.0)$. Accordingly, the calculated values of relative changes of $\triangle \mathrm{TA}$ versus $\Delta \mathrm{DIC}$ would require that $\mathrm{CaCO}_{3}$ dissolution corresponded to 34 and $48 \%$ of aerobic organic matter degradation. Such a large $\mathrm{CaCO}_{3}$ dissolution is very unlikely in the Mekong delta because $\mathrm{Ca}^{2+}$ and $\mathrm{Mg}^{2+}$ showed conservative mixing as a function of salinity (Fig. S3) and because particulate inorganic carbon (PIC) is relatively low in the Mekong delta compared to POC. The \%PIC of TSM $(\sim 0.1 \%)$ reported by Huang et al. (2017) is 1 order of magnitude lower than the \%POC of TSM (1$8 \%$ ) we report (Fig. 6). The values of the slope of the linear regression of $\Delta \mathrm{TA}$ versus $\Delta \mathrm{DIC}$ (range $0.55-0.87$ ) were intermediary between the theoretical slopes for aerobic organic matter degradation $(\triangle \mathrm{TA}: \triangle \mathrm{DIC}=-0.2)$ and sulfate reduction $(\triangle \mathrm{TA}: \triangle \mathrm{DIC}=0.9)$, suggesting that $\mathrm{TA}$ and $\mathrm{DIC}$ were produced from the combination of these two processes. Such a scenario is very likely with sulfate reduction dominating in the sediments and aerobic respiration dominating 

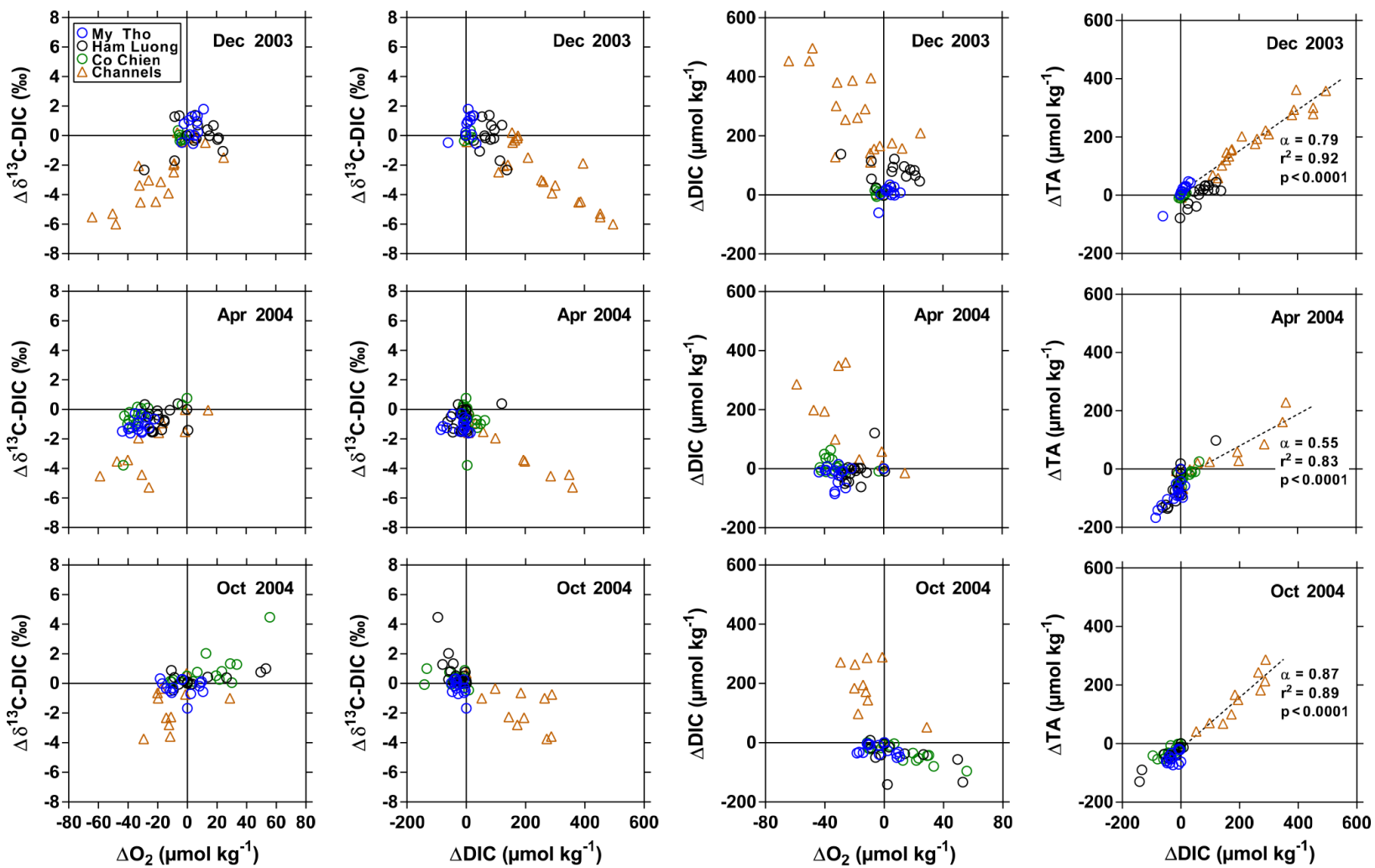

Figure 8. Deviations from conservative mixing lines of stable isotope composition of dissolved inorganic carbon (DIC) ( $\Delta \delta^{13} \mathrm{C}$-DIC, $\%$ o as a function of $\mathrm{O}_{2}\left(\Delta \mathrm{O}_{2}, \mu \mathrm{mol} \mathrm{kg}{ }^{-1}\right)$ and of DIC $(\Delta \mathrm{DIC}, \mu \mathrm{mol} \mathrm{kg}-1)$, of $\Delta$ DIC as a function of $\Delta \mathrm{O}_{2}$, and of total alkalinity $(\Delta \mathrm{TA}, \mu \mathrm{mol} \mathrm{kg}-1)$ as function of $\triangle \mathrm{DIC}$ in the three branches of the Mekong delta (Mỹ Tho, Hàm Luông, and Cố Chiên) and side channels in December 2003, April 2004, and October 2004. $\alpha$ indicates the slope of the linear regression line (dotted line).

in the water column. Our data do not allow us to determine whether these processes mainly occurred in the side channels or in the shrimp farming ponds themselves, although Alongi et al. (1999b) showed a strong dominance of aerobic respiration over other diagenetic degradation processes in sediments of shrimp ponds in the Ca Mau province. This would then suggest that sulfate reduction was mostly occurring within the side channels. The $\Delta \mathrm{TA}: \triangle \mathrm{DIC}$ slope from the side channels correlated negatively to average salinity (Fig. 9), which is counter-intuitive since a higher contribution of sulfate reduction ( $\Delta \mathrm{TA}: \Delta \mathrm{DIC}$ ratio closer to 0.9 ) would have been expected at higher salinity (e.g. Borges and Abril, 2011). This pattern might result from a higher aerobic respiration in the water column of the side channels during the periods of low water (higher salinity) and/or a lower signal from sulfate reduction occurring within the shrimp farming ponds. The former scenario is consistent with the negative correlation between $\Delta \mathrm{O}_{2}$ and salinity (Fig. 9).

\subsection{Comparison with the Ca Mau mangrove creeks}

The $\mathrm{Ca}$ Mau peninsula accounts for the largest proportion of remaining mangrove forests in the Mekong delta system. Data were gathered in two mangrove creek networks (Tam
Giang and Kien Vang), allowing the comparison with data in the three estuarine channels of the Mekong delta (My Tho, Hàm Luông, and Cố Chiên) and associated side channels (hereafter referred to as Bến Tre Mekong delta, based on the name of the province), where the bordering mangrove forests have been cleared for the implementation of shrimp farming ponds. Data comparison is limited to the April and October 2004 cruises (Fig. 10). $\mathrm{pCO}_{2}$ was negatively related to $\% \mathrm{O}_{2}$ in Ca Mau creeks and the Bến Tre Mekong delta owing to organic matter degradation as confirmed by the positive relation between $\Delta \delta{ }^{13} \mathrm{C}$-DIC and $\% \mathrm{O}_{2}$. Data in the $\mathrm{Ca}$ Mau mangrove creeks allowed us to expand the range of variations in $\mathrm{pCO}_{2}, \% \mathrm{O}_{2}$, and $\delta^{13} \mathrm{C}$-DIC; the maximum $\mathrm{pCO}_{2}$ value in the $\mathrm{Ca}$ Mau mangrove creeks was $6912 \mathrm{ppm}$ compared to $2926 \mathrm{ppm}$ in the Bến Tre Mekong delta; the minimum $\% \mathrm{O}_{2}$ and $\delta^{13} \mathrm{C}$-DIC values were, respectively, $37 \%$ and $-14.6 \%$ in the Ca Mau mangrove creeks compared to $66 \%$ and $-11.4 \%$ in the Bến Tre Mekong delta. As previously noted by Borges and Abril (2011), the spatial variations in $\mathrm{pCO}_{2}$ and $\% \mathrm{O}_{2}$ in the $\mathrm{Ca} \mathrm{Mau}$ mangrove creeks were related to the size of the creeks, the narrower and presumably shallower creeks being characterized by higher $\mathrm{pCO}_{2}$ values and lower $\% \mathrm{O}_{2}$ and $\delta^{13} \mathrm{C}$-DIC values. Salinity was highly 
Table 1. Average \pm standard deviation in air-water fluxes of $\mathrm{CO}_{2}\left(F \mathrm{CO}_{2}, \mathrm{mmol} \mathrm{m}^{-2} \mathrm{~d}^{-1}\right)$ and $\mathrm{CH}_{4}\left(F \mathrm{CH}_{4}, \mu \mathrm{mol} \mathrm{m}{ }^{-2} \mathrm{~d}^{-1}\right)$, and wind speed $\left(\mathrm{m} \mathrm{s}^{-1}\right)$ in December 2003, April 2004, and October 2004 in the three inner estuarine branches of the Mekong delta (My Tho, Hàm Luông, and Cố Chiên), respective river plume and side channels, and in the Ca Mau province mangrove creeks.

\begin{tabular}{|c|c|c|c|}
\hline & $\begin{array}{r}F \mathrm{CO}_{2} \\
\left(\mathrm{mmol} \mathrm{m}^{-2} \mathrm{~d}^{-1}\right)\end{array}$ & $\begin{array}{r}F \mathrm{CH}_{4} \\
\left(\mu \mathrm{mol} \mathrm{m}{ }^{-2} \mathrm{~d}^{-1}\right)\end{array}$ & $\begin{array}{r}\text { Wind speed } \\
\quad\left(\mathrm{m} \mathrm{s}^{-1}\right)\end{array}$ \\
\hline \multicolumn{4}{|l|}{ December 2003} \\
\hline Inner estuarine branches (IEBs) & $122 \pm 33$ & & \\
\hline River plume (RB) & $56 \pm 25$ & & \\
\hline $\mathrm{IEB}+\mathrm{RB}$ & $90 \pm 33$ & & $5.3 \pm 3.2$ \\
\hline Side channels & $85 \pm 45$ & & $4.6 \pm 3.6$ \\
\hline \multicolumn{4}{|l|}{ April 2004} \\
\hline Inner estuarine branches & $105 \pm 64$ & $43 \pm 14$ & \\
\hline River plume & $18 \pm 6$ & $7 \pm 4$ & \\
\hline $\mathrm{IEB}+\mathrm{RB}$ & $69 \pm 35$ & $29 \pm 12$ & $8.1 \pm 2.9$ \\
\hline Side channels & $37 \pm 31$ & $19 \pm 17$ & $5.1 \pm 1.3$ \\
\hline Ca Mau mangrove creeks & $61 \pm 68$ & $22 \pm 17$ & $3.5 \pm 3.5$ \\
\hline \multicolumn{4}{|l|}{ October 2004} \\
\hline Inner estuarine branches & $135 \pm 73$ & $193 \pm 162$ & \\
\hline River plume & $44 \pm 129$ & $46 \pm 9$ & \\
\hline $\mathrm{IEB}+\mathrm{RB}$ & $70 \pm 159$ & $87 \pm 32$ & $6.1 \pm 5.7$ \\
\hline Side channels & $88 \pm 19$ & $701 \pm 890$ & $3.8 \pm 3.0$ \\
\hline Ca Mau mangrove creeks & $116 \pm 78$ & $298 \pm 224$ & $3.9 \pm 2.6$ \\
\hline \multicolumn{4}{|l|}{ Average of cruises } \\
\hline Inner estuarine branches & $121 \pm 57$ & $118 \pm 68$ & \\
\hline River plume & $39 \pm 49$ & $26 \pm 10$ & \\
\hline $\mathrm{IEB}+\mathrm{RB}$ & $76 \pm 80$ & $58 \pm 23$ & \\
\hline Side channels & $70 \pm 37$ & $360 \pm 387$ & \\
\hline $\mathrm{Ca}$ Mau mangrove creeks & $89 \pm 79$ & $160 \pm 121$ & \\
\hline
\end{tabular}

variable among the two sampling cruises (Fig. 11), on average 33.2 in April 2004 and 14.1 in October 2004 (MW test $p<0.0001$ ), following the hydrological cycle (Fig. 2). The seasonal variations in $\mathrm{CH}_{4}$ were also very marked (MW test $p<0.0001$ ), with much lower values in April 2004 (range $4-46 \mathrm{nmol} \mathrm{L}^{-1}$, average $19 \mathrm{nmol} \mathrm{L}^{-1}$ ) than in October 2004 (range $19-686 \mathrm{nmol} \mathrm{L}^{-1}$, average $210 \mathrm{nmol} \mathrm{L}^{-1}$ ). This is probably related to the seasonal salinity changes, the lowest $\mathrm{CH}_{4}$ values corresponding to the highest salinities (Fig. 11). We hypothesize that the increase in salinity leads to an increase in benthic sulfate reduction due to the increase in $\mathrm{SO}_{4}^{2-}$ availability and a decrease in the transfer of $\mathrm{CH}_{4}$ from sediments to the water column due to a partial inhibition of methanogenesis and/or an enhancement of anaerobic $\mathrm{CH}_{4}$ oxidation. Such a hypothesis is consistent with the negative relationship in mangroves between sediment-air $\mathrm{CH}_{4}$ fluxes and salinity (Borges and Abril, 2011). The $\mathrm{pCO}_{2}$ was higher and $\% \mathrm{O}_{2}$ was lower in October than April 2004, although the differences are not as dramatic as for $\mathrm{CH}_{4}$, albeit statistically significant (Fig. 11). This could indicate the occurrence during the rainy season (October) of the input of high- $\mathrm{CO}_{2}$ and low- $\mathrm{O}_{2}$ waters or additional organic matter (that fuelled remineralization) from freshwater (surface run-off). In October 2004, the $\mathrm{CH}_{4}$ concentrations in the Ca Mau mangroves were generally higher than in the Bến Tre Mekong delta three main channels; however, the highest $\mathrm{CH}_{4}$ concentrations were recorded in the side channels of the Bến Tre Mekong delta, most probably resulting from intense methanogenesis fuelled by high organic matter loads from the shrimp farming ponds.

\section{4 $\mathrm{CO}_{2}$ and $\mathrm{CH}_{4}$ emissions to the atmosphere}

As expected from the distribution of $\mathrm{pCO}_{2}$, the $\mathrm{FCO}_{2}$ values were higher in the inner estuarine branches (Mỹ Tho, Hàm Luông, Cố Chiên) than in the outer estuary (river plume) and the side channels (Table 1). In addition, wind speed was lower in the side channels and mangrove creeks than in the more open waters of the inner and outer estuaries. Although the $\mathrm{pCO}_{2}$ in the side channels was higher than in the adjacent inner estuarine branches at similar salinities (Fig. 6), the overall $\mathrm{pCO}_{2}$ within the inner estuarine branches was higher, 

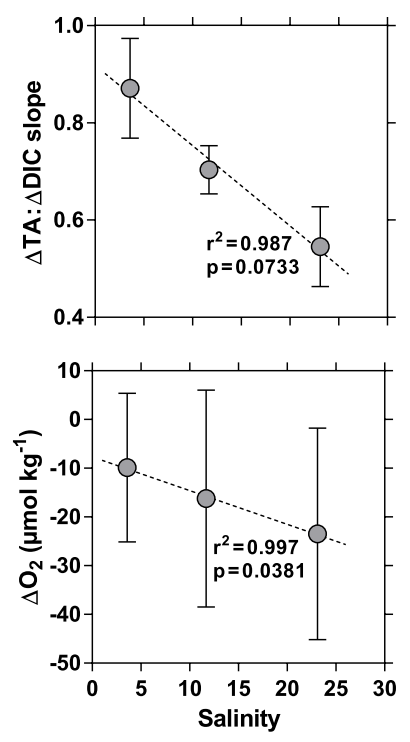

Figure 9. Variation as a function of salinity of the slope of the regression line of the deviation from conservative mixing lines of total alkalinity $\left(\Delta \mathrm{TA}, \mu \mathrm{mol} \mathrm{kg}{ }^{-1}\right)$ and of dissolved inorganic carbon $\left(\Delta \mathrm{DIC}, \mu \mathrm{mol} \mathrm{kg}{ }^{-1}\right)$ of $\mathrm{O}_{2}\left(\Delta \mathrm{O}_{2}, \mu \mathrm{mol} \mathrm{kg}{ }^{-1}\right)$ in the side channels of the Mekong delta in December 2003, April 2004, and October 2004. The dotted line indicates the linear regression. Error bars indicate standard deviation.

owing to high values in the upper estuary. Despite some variations in wind speed among the cruises, the seasonal variations in $\mathrm{FCO}_{2}$ in the inner estuarine branches followed the seasonal hydrological cycle, with the highest $\mathrm{FCO}_{2}$ values in October 2004 during high water and the lowest $\mathrm{FCO}_{2}$ values in April 2004 during low water (Table 1). The $F_{C^{2}}$ values in the inner estuarine branches were well correlated to freshwater discharge (Fig. 12). This indicates that the $F \mathrm{CO}_{2}$ seasonal variations are related to the riverine inputs either directly as $\mathrm{CO}_{2}$ or as organic matter that can be degraded within the estuary. During our cruises seasonal variations in water temperature were weak (range $26.7-31.5^{\circ} \mathrm{C}$, on average $29.2^{\circ} \mathrm{C}$ ), owing to the subtropical climate. Consequently, marked seasonality of $\mathrm{pCO}_{2}$ and $F \mathrm{CO}_{2}$ due to modulation of biological activity by water temperature does not occur, unlike in temperate estuaries (for example Frankignoulle et al., 1998). The potential contribution of riverine organic carbon and $\mathrm{CO}_{2}$ inputs in sustaining estuarine $\mathrm{FCO}_{2}$ was computed from freshwater discharge multiplied by POC and excess DIC (EDIC, computed as the difference between observed DIC and DIC computed from TA and the atmospheric $\mathrm{pCO}_{2}$ value; Abril et al., 2000). The average for the three cruises of riverine input of POC $\left(60 \times 10^{6} \mathrm{~mol} \mathrm{~d}^{-1}\right)$ and EDIC $\left(53 \times 10^{6} \mathrm{~mol} \mathrm{~d}^{-1}\right)$ exceeded $F \mathrm{CO}_{2}$ in the three estuarine branches $\left(53 \times 10^{6} \mathrm{~mol} \mathrm{~d}^{-1}\right)$, showing that these inputs were sufficient to sustain the $\mathrm{CO}_{2}$ emissions from the estuary and that part of the riverine POC and EDIC is transported to the outer estuary (river plume). $\mathrm{FCO}_{2}$ in the side channels

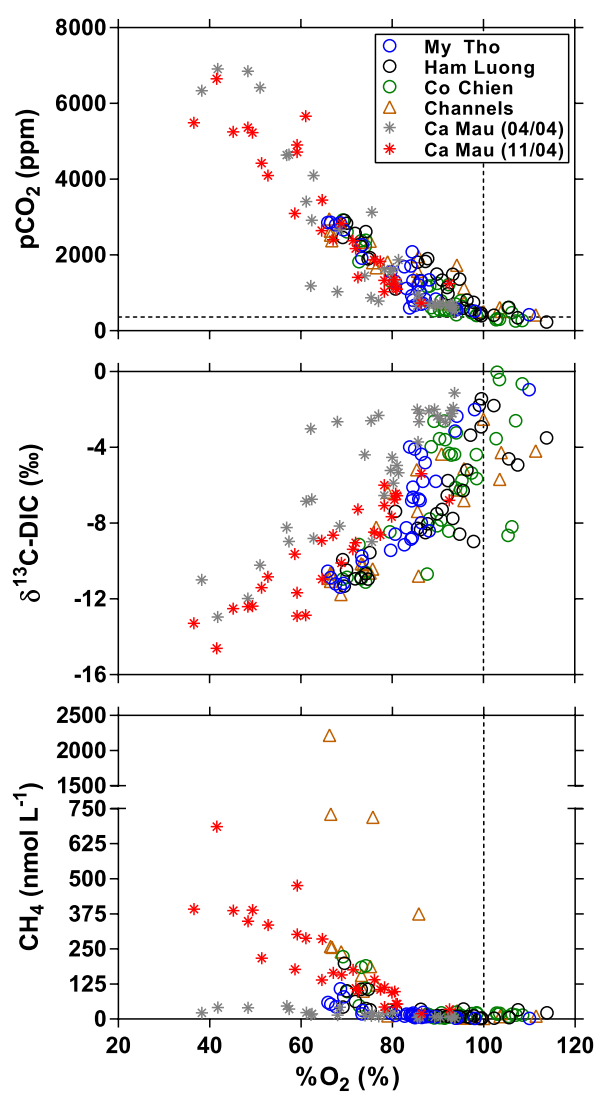

Figure 10. Distribution as a function of oxygen saturation level $\left(\% \mathrm{O}_{2}, \%\right)$ of the partial pressure of $\mathrm{CO}_{2}\left(\mathrm{pCO}_{2}, \mathrm{ppm}\right)$, stable isotope composition of dissolved inorganic carbon $\left(\delta^{13} \mathrm{C}\right.$-DIC, $\%$ ), and dissolved $\mathrm{CH}_{4}$ concentration $\left(\mathrm{nmol} \mathrm{L}^{-1}\right)$ in the three branches of the Mekong delta (Mỹ Tho, Hàm Luông, and Cố Chiên) and side channels and in the mangrove creeks of the $\mathrm{Ca}$ Mau province in April and October 2004. The vertical dotted line indicates $\mathrm{O}_{2}$ saturation $(100 \%)$; the horizontal line indicates the average atmospheric $\mathrm{pCO}_{2}$ value.

and outer estuary (or river plume) also showed a less significant correlation with water discharge (Fig. 12) because processes other than riverine inputs such as the inputs of carbon from the shrimp farming ponds for side channels and primary production for the outer estuary control $\mathrm{CO}_{2}$ dynamics in these systems. A phytoplankton bloom in the river plume in October 2004 explains why $\mathrm{FCO}_{2}$ values were equivalent to those in December 2003, although freshwater discharge was about 2 times lower. 

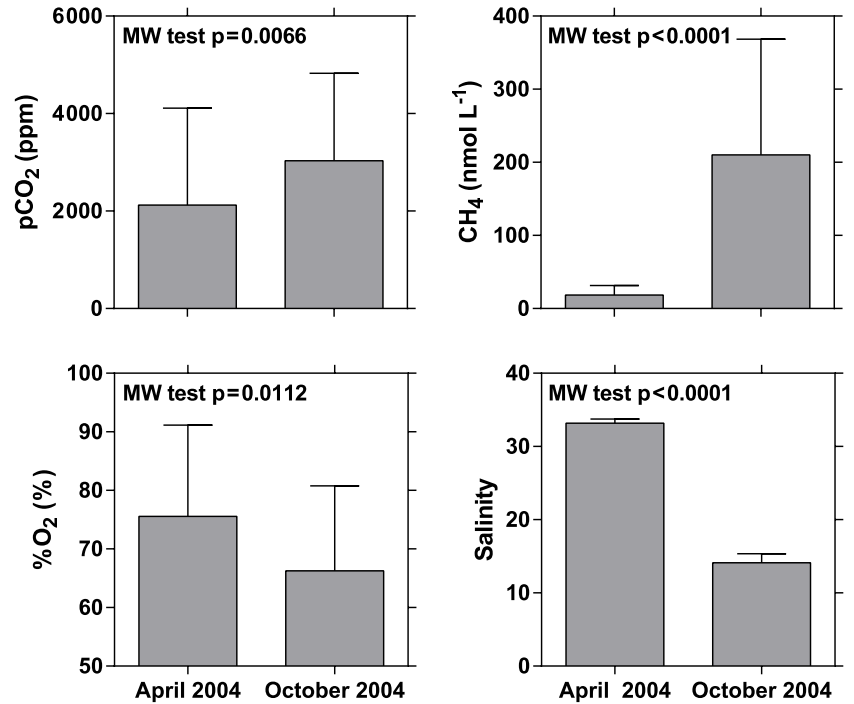

Figure 11. Average \pm standard deviation of the partial pressure of $\mathrm{CO}_{2}\left(\mathrm{pCO}_{2}, \mathrm{ppm}\right)$, oxygen saturation level $\left(\% \mathrm{O}_{2}, \%\right)$, dissolved $\mathrm{CH}_{4}$ concentration $\left(\mathrm{nmol} \mathrm{L}{ }^{-1}\right.$ ), and salinity in the mangrove creeks of the Ca Mau province in April and October 2004. MW: MannWhitney (at 0.05 level).

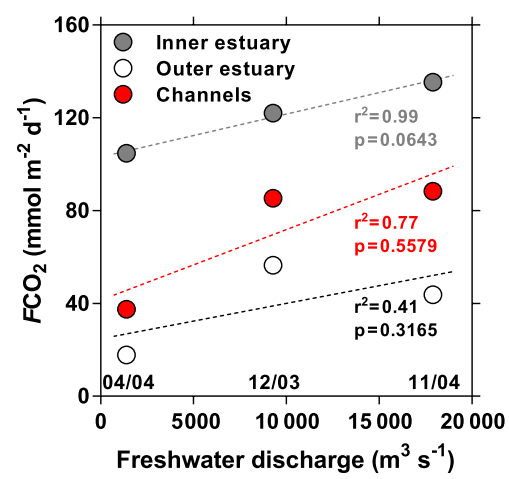

Figure 12. Average air-water $\mathrm{CO}_{2}$ fluxes $\left(\mathrm{FCO}_{2}, \mathrm{mmol} \mathrm{m}^{-2} \mathrm{~d}^{-1}\right)$ in the inner and outer estuaries and side channels of the Mekong delta as a function of freshwater discharge $\left(\mathrm{m}^{3} \mathrm{~s}^{-1}\right)$ in December 2003, April 2004, and October 2004. Sampling dates (mm/yy) are indicated in the bottom of the panel. Dotted lines indicate the linear regression lines.

Differences of $\mathrm{FCH}_{4}$ between the two 2004 cruises were very marked, with values in inner estuarine branches more than 4 times higher in October than April 2004 (MW test $p<0.0001$ ). In April 2004, the $F \mathrm{CH}_{4}$ values in the side channels of the Bến Tre Mekong delta were equivalent to those in the Ca Mau mangrove creeks but were more than 2 times higher in October 2004.

The average $F_{C O}$ in the inner estuarine branches of the Mekong delta $\left(118 \mathrm{mmol} \mathrm{m}^{-2} \mathrm{~d}^{-1}\right)$ is higher than in the Pearl River inner estuary $\left(46 \mathrm{mmol} \mathrm{m}^{-2} \mathrm{~d}^{-1}\right.$; Guo et al., 2009) and the Yangtze River inner estuary $\left(41 \mathrm{mmol} \mathrm{m}^{-2} \mathrm{~d}^{-1}\right.$, Zhai et al., 2007), the two other major river systems bordering the East China Sea that have been documented for $\mathrm{CO}_{2}$ dynamics. The higher value in the Mekong is probably related to the dominance of freshwater in the inner estuary and low intrusion of seawater within the estuary, related to the geomorphology (relatively narrow and linear estuarine channels, compared to the typical "funnel" shape estuarine morphology in the Yangtze and Pearl river estuaries). Indeed, the average salinity in the Pearl River inner estuary was 17 (Guo et al., 2009), higher than the average salinity of 4 in the Mekong inner estuarine branches during our cruises. The average $\mathrm{FCO}_{2}$ in the $\mathrm{Ca}$ Mau mangrove creeks $\left(89 \mathrm{mmol} \mathrm{m}^{-2}\right.$ $\left.\mathrm{d}^{-1}\right)$ was well within the range $\left(-8-862 \mathrm{mmol} \mathrm{m}^{-2} \mathrm{~d}^{-1}\right)$ and close to the average $\left(63 \mathrm{mmol} \mathrm{m}^{-2} \mathrm{~d}^{-1}\right)$ of $\mathrm{CO}_{2}$ fluxes in mangrove estuarine creeks compiled globally by Rosentreter et al. (2018).

The $\mathrm{FCH}_{4}$ seasonal variations within a given estuary and the $\mathrm{FCH}_{4}$ variations from one estuary to another are notoriously large; thus, comparison of the $\mathrm{FCH}_{4}$ in the Mekong delta with previously published studies is not easy. The average $\mathrm{FCH}_{4}$ value in the inner estuarine branches of the Mekong delta $\left(118 \mu \mathrm{mol} \mathrm{m} \mathrm{m}^{-2} \mathrm{~d}^{-1}\right)$ is within the range of values in European estuaries $\left(17-1352 \mu \mathrm{mol} \mathrm{m}^{-2} \mathrm{~d}^{-1}\right)$ compiled by Upstill-Goddard and Barnes (2016) but distinctly higher than the range of values for Indian estuaries (7$15 \mu \mathrm{mol} \mathrm{m}{ }^{-2} \mathrm{~d}^{-1}$ ) reported by Rao and Sarma (2016). The $\mathrm{FCH}_{4}$ in the Yangtze and Pearl river estuaries reported by Zhang et al. (2008) and Zhou et al. (2009) of 61 and $64 \mu \mathrm{mol}$ $\mathrm{m}^{-2} \mathrm{~d}^{-1}$, respectively, are also higher than the range of $\mathrm{FCH}_{4}$ in Indian estuaries. The $F \mathrm{CH}_{4}$ in the Mekong delta inner estuarine branches was higher than the value in the Yangtze River and Pearl River estuaries probably because of the lower intrusion of seawater into the Mekong delta (see above). The average $\mathrm{FCH}_{4}$ in the $\mathrm{Ca}$ Mau mangrove creeks $\left(160 \mu \mathrm{mol} \mathrm{m} \mathrm{m}^{-2} \mathrm{~d}^{-1}\right)$ was well within the range $(9-409 \mu \mathrm{mol}$ $\left.\mathrm{m}^{-2} \mathrm{~d}^{-1}\right)$ and close to the average $\left(283 \mu \mathrm{mol} \mathrm{m}^{-2} \mathrm{~d}^{-1}\right)$ of $\mathrm{CH}_{4}$ fluxes in mangrove estuarine creeks compiled globally by Call et al. (2015).

Data availability. The full data set is available in tabular form in the Supplement (Table S1).

Supplement. The supplement related to this article is available online at: https://doi.org/10.5194/bg-15-1093-2018-supplement.

Author contributions. AVB designed the experiment and carried out sample collection in the field. AVB, SB, and GA analysed the samples, interpreted the data, and drafted the paper.

Competing interests. The authors declare that they have no conflict of interest. 
Special issue statement. This article is part of the special issue "Human impacts on carbon fluxes in Asian river systems". It is not associated with a conference.

Acknowledgements. We are extremely grateful to the Research Institute for Aquaculture No. 2 (Ho Chi Minh City) and the Bến Tre Fishery Department for logistical support during the collection of samples. Freshwater discharge data were kindly provided by Nguyen Hong Quang from the Vietnam National Satellite Center. This work was funded by the Fonds National de la Recherche Scientifique (FNRS) (1.5.066.03); the publication charge was covered by the Asia-Pacific Network for Global Change Research (CRRP2016-01MY-Park) support to the special issue. We thank three reviewers for constructive comments on a previous version of the paper. Alberto V. Borges is a senior research associate at the FNRS.

Edited by: Ji-Hyung Park

Reviewed by: two anonymous referees

\section{References}

Abril, G. and Borges, A. V.: Carbon dioxide and methane emissions from estuaries, in: Greenhouse Gases Emissions from Natural Environments and Hydroelectric Reservoirs: Fluxes and Processes. Environmental Science Series, edited by: Tremblay, A., Varfalvy, L., Roehm, C., and Garneau, M., Springer-Verlag Berlin, New York, 187-207, 2004.

Abril, G., Etcheber, H., Borges, A. V., and Frankignoulle, M.: Excess atmospheric carbon dioxide transported by rivers into the Scheldt estuary, C. R. Seances Acad. Sci. III, 330, 761-768, https://doi.org/10.1016/S1251-8050(00)00231-7, 2000.

Abril, G., Nogueira, M., Etcheber, H., Cabecadas, G., Lemaire, E., and Brogueira, M. J.: Behaviour of organic carbon in nine contrasting European estuaries, Estuar. Coast. Shelf S., 54, 241-262, https://doi.org/10.1006/ecss.2001.0844, 2002.

Abril, G., Bouillon, S., Darchambeau, F., Teodoru, C. R., Marwick, T. R., Tamooh, F., Ochieng Omengo, F., Geeraert, N., Deirmendjian, L., Polsenaere, P., and Borges, A. V.: Technical Note: Large overestimation of $p \mathrm{CO}_{2}$ calculated from $\mathrm{pH}$ and alkalinity in acidic, organic-rich freshwaters, Biogeosciences, 12, 67-78, https://doi.org/10.5194/bg-12-67-2015, 2015.

Adamson, P. T., Rutherfurd, I. D., Peel, M. C., and Conlan, I. A.: The Hydrology of the Mekong River, in: The Mekong, edited by: Ian, C. C., Academic Press, San Diego, 53-76, 2009.

Alin, S. R., Rasera, M. F. F. L., Salimon, C. I., Richey, J. E., Holtgrieve, G. W., and Krusche, A. V., and Snidvongs, A.: Physical controls on carbon dioxide transfer velocity and flux in low-gradient river systems and implications for regional carbon budgets, J. Geophys. Res., 116, G01009, https://doi.org/10.1029/2010JG001398, 2011.

Alongi, D. M., Dixon, P., Johnston, D. J., Tien, D. V., and Xuan, T. T.: Pelagic processes in extensive shrimp ponds of the Mekong delta, Vietnam, Aquaculture, 175, 121-141, https://doi.org/10.1016/S0044-8486(99)00078-2, 1999a.

Alongi, D. M., Tirendi, F., and Trott, L. A.: Rates and pathways of benthic mineralization in extensive shrimp ponds of the Mekong delta, Vietnam, Aquaculture, 175, 269-292, https://doi.org/10.1016/S0044-8486(99)00077-0, 1999b.

Alongi, D. M., Johnston, D. J., and Xuan, T. T.: Carbon and nitrogen budgets in shrimp ponds of extensive mixed shrimp-mangrove forestry farms in the Mekong delta, Vietnam, Aquacult. Res., 31, 387-399, https://doi.org/10.1046/j.1365-2109.2000.00457.x, 2000.

Amiotte Suchet, P., Probst, J., and Ludwig, W.: Worldwide distribution of continental rock lithology: Implications for the atmospheric/soil $\mathrm{CO}_{2}$ uptake by continental weathering and alkalinity river transport to the oceans, Global Biogeochem. Cy., 17, 1038, https://doi.org/10.1029/2002GB001891, 2003.

Anthony, E. J., Brunier, G., Besset, M., Goichot, M., Dussouillez, P., and Nguyen, V. L.: Linking rapid erosion of the Mekong River delta to human activities, Sci. Rep., 5, 14745, https://doi.org/10.1038/srep14745, 2015.

Bange, H. W., Bartell, U. H., Rapsomanikis, S., and Andrea, M. O.: Methane in the Baltic and North Seas and a reassessment of the marine emissions of methane, Global Biogeochem. Cy., 8, 465480, https://doi.org/10.1029/94GB02181, 1994.

Bastviken, D., Tranvik, L. J., Downing, J. A., Crill, P. M., and Enrich-Prast, A.: Freshwater methane emissions offset the continental carbon sink, Science, 331, 50 pp., https://doi.org/10.1126/science.1196808, 2011.

Bates, T. S., Kelly, K. C., Johnson, J. E., and Gammon, R. H.: A reevaluation of the open ocean source of methane to the atmosphere, J. Geophys. Res., 101, 6953-6961, https://doi.org/10.1029/95JD03348, 1996.

Bianchi, T. S.: Biogeochemistry of Estuaries, Oxford University Press, 720 pp., 2006.

Borges, A. V.: Do we have enough pieces of the jigsaw to integrate $\mathrm{CO}_{2}$ fluxes in the coastal ocean?, Estuaries, 28, 3-27, https://doi.org/10.1007/bf02732750, 2005.

Borges, A. V. and Abril, G.: Carbon dioxide and methane dynamics in estuaries, in: Treatise on Estuarine and Coastal Science, edited by: Wolanski, E. and McLusky, D., Academic Press, Waltham, 119-161, 2011.

Borges, A. V., Djenidi, S., Lacroix, G., Théate, J., Delille, B., and Frankignoulle, M.: Atmospheric $\mathrm{CO}_{2}$ flux from mangrove surrounding waters, Geophys. Res. Lett., 30, 1558, https://doi.org/10.1029/2003GL017143, 2003.

Borges, A. V., Delille, B., Schiettecatte, L.-S., Gazeau, F., Abril, G., and Frankignoulle, M.: Gas transfer velocities of $\mathrm{CO}_{2}$ in three European estuaries (Randers Fjord, Scheldt and Thames), Limnol. Oceanogr., 49, 1630-1641, https://doi.org/10.4319/lo.2004.49.5.1630, 2004.

Borges, A. V., Delille, B., and Frankignoulle, M.: Budgeting sinks and sources of $\mathrm{CO}_{2}$ in the coastal ocean: Diversity of ecosystems counts, Geophys. Res. Lett., 32, L14601, https://doi.org/10.1029/2005g1023053, 2005.

Borges, A. V., Schiettecatte, L.-S., Abril, G., Delille, B., and Gazeau, E.: Carbon dioxide in European coastal waters, Estuar. Coast. Shelf S., 70, 375-387, https://doi.org/10.1016/j.ecss.2006.05.046, 2006.

Borges, A. V., Darchambeau, F., Teodoru, C. R., Marwick, T. R., Tamooh, F., Geeraert, N., Omengo, F. O., Guérin, F., Lambert, T., Morana, C., Okuku, E., and Bouillon, S.: Globally significant greenhouse gas emissions from African inland waters, Nat. Geosci., 8, 637-642, https://doi.org/10.1038/NGEO2486, 2015a. 
Borges, A. V., Abril, G., Darchambeau, F., Teodoru, C. R., Deborde, J., Vidal, L. O., Lambert, T., and Bouillon, S.: Divergent biophysical controls of aquatic $\mathrm{CO}_{2}$ and $\mathrm{CH}_{4}$ in the World's two largest rivers, Sci. Rep., 5, 15614, https://doi.org/10.1038/srep15614, $2015 b$.

Borges, A. V., Champenois, W., Gypens, N., Delille, B., and Harlay, J.: Massive marine methane emissions from near-shore shallow coastal areas, Sci. Rep., 6, 27908, https://doi.org/10.1038/srep27908, 2016.

Borges, A. V., Speeckaert, G., Champenois, W., Scranton, M. I., and Gypens, N.: Productivity and temperature as drivers of seasonal and spatial variations of dissolved methane in the Southern Bight of the North Sea, Ecosystems, 1-17, https://doi.org/10.1007/s10021-017-0171-7, 2017.

Bouillon, S., Korntheuer, M., Baeyens, W., and Dehairs, F.: A new automated setup for stable isotope analysis of dissolved organic carbon, Limnol. Oceanogr.-Meth., 4, 216-226, https://doi.org/10.4319/lom.2006.4.216, 2006.

Bouillon, S., Dehairs, F., Schiettecatte, L.-S., and Borges, A. V.: Biogeochemistry of the Tana estuary and delta (northern Kenya), Limnol. Oceanogr., 52, 46-59, https://doi.org/10.4319/lo.2007.52.1.0046, 2007a.

Bouillon, S., Dehairs, F., Velimirov, B., Abril, G., and Borges, A. V.: Dynamics of organic and inorganic carbon across contiguous mangrove and seagrass systems (Gazi Bay, Kenya), J. Geophys. Res., 112, G02018, https://doi.org/10.1029/2006jg000325, 2007b.

Bouillon, S., Gillikin, D. P., and Connolly, R. M.: Use of stable isotopes to understand food webs and ecosystem functioning in estuaries, in: Treatise on Estuarine and Coastal Science, edited by: Wolanski, E. and McLusky, D. S., 7, 143-173, Waltham: Academic Press, 2012a.

Bouillon, S., Yambélé, A., Spencer, R. G. M., Gillikin, D. P., Hernes, P. J., Six, J., Merckx, R., and Borges, A. V.: Organic matter sources, fluxes and greenhouse gas exchange in the Oubangui River (Congo River basin), Biogeosciences, 9, 2045-2062, https://doi.org/10.5194/bg-9-2045-2012, 2012 b.

Bouillon, S., Yambélé, A., Gillikin, D. P., Teodoru, C., Darchambeau, F., Lambert, T., and Borges, A. V.: Contrasting biogeochemical characteristics of right-bank tributaries and a comparison with the mainstem Oubangui River, Central African Republic (Congo River basin), Sci. Rep., 4, 5402, https://doi.org/10.1038/srep05402, 2014.

Brewer, P. G. and Goldman, J. C.: Alkalinity changes generated by phytoplankton growth, Limnol. Oceanogr., 21, 108-117, https://doi.org/10.4319/lo.1976.21.1.0108, 1976.

Cai, W.-J.: Estuarine and coastal ocean carbon paradox: $\mathrm{CO}_{2}$ sinks or sites of terrestrial carbon incineration?, Annu. Rev. Mar. Sci., 3, 123-145, https://doi.org/10.1146/annurev-marine120709-142723, 2011.

Cai, W.-J. and Wang, Y.: The chemistry, fluxes, and sources of carbon dioxide in the estuarine waters of the Satilla and Altamaha Rivers, Georgia, Limnol. Oceanogr., 43, 657-668, https://doi.org/10.4319/lo.1998.43.4.0657, 1998.

Cai, W.-J., Guo, X., Chen, C.-T. A., Dai, M., Zhang, L., Zhai, W., Lohrenz, S. E., Yin, K., Harrison, P. J., and Wang, Y.: A comparative overview of weathering intensity and $\mathrm{HCO}_{3}^{-}$flux in the world's major rivers with emphasis on the Changjiang, Huanghe,
Zhujiang (Pearl) and Mississippi Rivers, Cont. Shelf Res., 28, 1538-1549, https://doi.org/10.1016/j.csr.2007.10.014, 2008.

Call, M., Maher, D. T., Santos, I. R., Ruiz-Halpern, S., Mangion, P., Sanders, C. J., Erler, D. V., Oakes, J. M., Rosentreter, J., Murray, R., and Eyre, B. D.: Spatial and temporal variability of carbon dioxide and methane fluxes over semi-diurnal and spring-neapspring timescales in a mangrove creek, Geochim. Cosmochim. Ac., 150, 211-225, https://doi.org/10.1016/j.gca.2014.11.023, 2015.

Cardozo, A. P. and Odebrecht, C.: Effects of shrimp pond water on phytoplankton: importance of salinity and trophic status of the receiving environment, Aquacult. Res., 45, 1600-1610, https://doi.org/10.1111/are.12106, 2014.

Chen, C.-T. A. and Borges, A. V.: Reconciling opposing views on carbon cycling in the coastal ocean: Continental shelves as sinks and near-shore ecosystems as sources of atmospheric $\mathrm{CO}_{2}$, Deep-Sea Res., 56, 578-590, https://doi.org/10.1016/j.dsr2.2009.01.001, 2009.

Chen, C.-T. A., Huang, T. H., Fu, Y. H., Bai, Y., and He, X.: Strong sources of $\mathrm{CO}_{2}$ in upper estuaries become sinks of $\mathrm{CO}_{2}$ in large river plumes, Curr. Opin. Env. Sust., 4, 179-185, https://doi.org/10.1016/j.cosust.2012.02.003, 2012.

Chen, C.-T. A., Huang, T.-H., Chen, Y.-C., Bai, Y., He, X., and Kang, Y.: Air-sea exchanges of $\mathrm{CO}_{2}$ in the world's coastal seas, Biogeosciences, 10, 6509-6544, https://doi.org/10.5194/bg-106509-2013, 2013.

Cotovicz Jr., L. C., Knoppers, B. A., Brandini, N., Costa Santos, S. J., and Abril, G.: A strong $\mathrm{CO}_{2}$ sink enhanced by eutrophication in a tropical coastal embayment (Guanabara Bay, Rio de Janeiro, Brazil), Biogeosciences, 12, 6125-6146, https://doi.org/10.5194/bg-12-6125-2015, 2015.

Crosswell, J. R., Wetz, M. S., Hales, B., and Paerl, H. W.: Air-water $\mathrm{CO}_{2}$ fluxes in the microtidal Neuse River Estuary, North Carolina, J. Geophys. Res., 117, C08017, https://doi.org/10.1029/2012JC007925, 2012.

Dai, A. and Trenberth, K. E.: Estimates of freshwater discharge from continents: latitudinal and seasonal variations, J. Hydrometeorol., 3, 660-687, https://doi.org/10.1175/15257541(2002)003<0660:EOFDFC>2.0.CO;2, 2002.

Darby, S. E., Hackney, C. R., Leyland, J., Kummu, M., Lauri, H., Parsons, D. R., Best, J. L., Nicholas, A. P., and Aalto, R.: Fluvial sediment supply to a mega-delta reduced by shifting tropical-cyclone activity, Nature, 539, 276-279, https://doi.org/10.1038/nature19809, 2016.

de Graaf, G. J. and Xuan, T. T.: Extensive shrimp farming, mangrove clearance and marine fisheries in the southern provinces of Vietnam, Mangroves Salt Marshes, 2, 159-166, https://doi.org/10.1023/A:1009975210487, 1998.

Descy, J.-P., Darchambeau, F., Lambert, T., Stoyneva, M. P., Bouillon, S., Borges, A. V.: Phytoplankton dynamics in the Congo River, Freshwater Biol., 62, 87-101, https://doi.org/10.1111/fwb.12851, 2017.

Dürr, H. H., Laruelle, G. G., van Kempen, C. M., Slomp, C. P., Meybeck, M., and Middelkoop, H.: Worldwide typology of nearshore coastal systems: Defining the estuarine filter of river inputs to the oceans, Estuar. Coast., 34, 441-458, https://doi.org/10.1007/s12237-011-9381-y, 2011.

Ellis, E. E., Keil, R. G., Ingalls, A. E., Richey, J. E., and Alin, S. R.: Seasonal variability in the sources of particu- 
late organic matter of the Mekong River as discerned by elemental and lignin analyses, J. Geophys. Res., 117, G01038, https://doi.org/10.1029/2011JG001816, 2012.

Frankignoulle, M. and Borges, A. V.: Direct and indirect $\mathrm{pCO}_{2}$ measurements in a wide range of $\mathrm{pCO}_{2}$ and salinity values (the Scheldt estuary), Aquat. Geochem., 7, 267-273, https://doi.org/10.1023/A:1015251010481, 2001.

Frankignoulle, M., Bourge, I., and Wollast, R.: Atmospheric $\mathrm{CO}_{2}$ fluxes in a highly polluted estuary (The Scheldt), Limnol. Oceanogr., 41, 365-369, https://doi.org/10.4319/lo.1996.41.2.0365, 1996.

Frankignoulle, M., Abril, G., Borges, A., Bourge, I., Canon, C., Delille, B., Libert, E., and Théate, J.-M.: Carbon dioxide emission from European estuaries, Science, 282, 434-436, https://doi.org/10.1126/science.282.5388.434, 1998.

Froelich, P. N., Klinkhammer, G. P., Bender, M. L., Luedtke, N. A., Heath, G. R., Cullen, D., Dauphin, P., Hammond, D., Hartman, B., and Maynard, V.: Early oxidation of organic matter in pelagic sediments of the eastern equatorial Atlantic: suboxic diagenesis, Geochim. Cosmochim. Ac., 43, 1075-1090, https://doi.org/10.1016/0016-7037(79)90095-4, 1979.

$\mathrm{Fu}$, K. D., He, D. M., and Lu, X. X.: Sedimentation in the Manwan reservoir in the Upper Mekong and its downstream impacts, Quaternary Int., 186, 91-99, https://doi.org/10.1016/j.quaint.2007.09.041, 2008.

Gaillardet, J., Dupré, B., Louvat, P., and Allègre, C. J.: Global silicate weathering and $\mathrm{CO}_{2}$ consumption rates deduced from the chemistry of large rivers, Chem. Geol., 159, 3-30, https://doi.org/10.1016/S0009-2541(99)00031-5, 1999.

Gao, S., Wang, H., Liu, G., and Li, H.: Spatio-temporal variability of chlorophyll a and its responses to sea surface temperature, winds and height anomaly in the western South China Sea, Acta Oceanol. Sin., 32, 48-58, https://doi.org/10.1007/s13131013-0266-8, 2013.

Gattuso, J.-P., Frankignoulle, M., and Wollast, R.: Carbon and carbonate metabolism in coastal aquatic ecosystems, Annu. Rev. Ecol. Evol., 29, 405-433, https://doi.org/10.1146/annurev.ecolsys.29.1.405, 1998.

Grosse, J., Bombar, D., Doan, H. N., Nguyen, L. N., and Voss, M.: The Mekong River plume fuels nitrogen fixation and determines phytoplankton species distribution in the South China Sea during low- and high-discharge season, Limnol. Oceanogr., 55, 16681680, https://doi.org/10.4319/lo.2010.55.4.1668, 2010

Guo, X., Dai, M., Zhai, W., Cai, W.-J., and Chen, B.: $\mathrm{CO}_{2}$ flux and seasonal variability in a large subtropical estuarine system, the Pearl River Estuary, China, J. Geophys. Res., 114, G03013, https://doi.org/10.1029/2008JG000905, 2009.

Hellings, L., Dehairs, F., Tackx, M., Keppens, E., and Baeyens, W.: Origin and fate of organic carbon in the freshwater part of the Scheldt Estuary as traced by stable carbon isotope composition, Biogeochemistry, 47, 167-186, https://doi.org/10.1007/BF00994921, 1999.

Henry, W.: Experiments on the quantity of gases absorbed by water, at different temperatures, and under different pressures, Philos. T. R. Soc. Lond., 93, 29-274, https://doi.org/10.1098/rstl.1803.0004, 1803.

Huang, T. H., Chen, C. T. A., Tseng, H. C., Lou, J. Y., Wang, S. L., Yang, L., Kandasamy, S., Gao, X., Wang, J. T., Aldrian, E., Jacinto, G. S., Anshari, G. Z., Som- pongchaiyakul, P., and Wang, B. J.: Riverine carbon fluxes to the South China Sea, J. Geophys. Res.-Biogeo., 122, 1239-1259, https://doi.org/10.1002/2016JG003701, 2017.

Huang, W.-J., Cai, W.-J., Wang, Y., Lohrenz, S. E., and Murrell, M. C.: The carbon dioxide system on the Mississippi Riverdominated continental shelf in the northern Gulf of Mexico: 1. Distribution and air-sea $\mathrm{CO}_{2}$ flux, J. Geophys. Res., 120, 1429 1445, https://doi.org/10.1002/2014JC010498, 2015.

IPCC: Climate Change 2014: Impacts, Adaptation, and Vulnerability. Part A: Global and Sectoral Aspects. Contribution of Working Group II to the Fifth Assessment Report of the Intergovernmental Panel on Climate Change, edited by: Field, C. B., Barros, V. R., Dokken, D. J., Mach, K. J., Mastrandrea, M. D., Bilir, T. E., Chatterjee, M., Ebi, K. L., Estrada, Y. O., Genova, R. C., Girma, B., Kissel, E. S., Levy, A. N., MacCracken, S., Mastrandrea, P. R., and White, L. L., Cambridge University Press, Cambridge, 1132 pp., 2014.

Joesoef, A., Huang, W.-J., Gao, Y., and Cai, W.-J.: Air-water fluxes and sources of carbon dioxide in the Delaware Estuary: spatial and seasonal variability, Biogeosciences, 12, 6085-6101, https://doi.org/10.5194/bg-12-6085-2015, 2015.

Joesoef, A., Kirchman, D. L., Sommerfield, C. K., and Cai, W.J.: Seasonal variability of the inorganic carbon system in a large coastal plain estuary, Biogeosciences, 14, 4949-4963, https://doi.org/10.5194/bg-14-4949-2017, 2017.

Kirschke, S., Bousquet, P., Ciais, P., Saunois, M., Canadell, J. G., Dlugokencky, E. J., Bergamaschi, P., Bergmann, D., Blake, D. R., Bruhwiler, L., Cameron-Smith, P., Castaldi, S., Chevallier, F., Feng, L., Fraser, A., Heimann, M., Hodson, E. L., Houweling, S., Josse, B., Fraser, P. J., Krummel, P. B., Lamarque, J.F., Langenfelds, R. L., Le Quéré, C., Naik, V., O’Doherty, S., Palmer, P. I., Pison, I., Plummer, D., Poulter, B., Prinn, R. G., Rigby, M., Ringeval, B., Santini, M., Schmidt, M., Shindell, D. T., Simpson, I. J., Spahni, R., Steele, L. P., Strode, S. A., Sudo, K., Szopa, S., van der Werf, G. R., Voulgarakis, A., van Weele, M., Weiss, R. F., Williams, J. E., and Zeng, G.: Three decades of global methane sources and sinks, Nat. Geosci., 6, 813-823, https://doi.org/10.1038/ngeo1955, 2013.

Kondolf, G. M., Rubin, Z. K., and Minear, J. T.: Dams on the Mekong: Cumulative sediment starvation, Water Resour. Res. 50, 5158-5169, https://doi.org/10.1002/2013WR014651, 2014.

Koné, Y. J.-M. and Borges, A. V.: Dissolved inorganic carbon dynamics in the waters surrounding forested mangroves of the Ca Mau Province (Vietnam), Estuar. Coast. Shelf S., 77, 409-421, https://doi.org/10.1016/j.ecss.2007.10.001, 2008.

Koné, Y. J. M., Abril, G., Kouadio, K. N., Delille, B., and Borges, A. V.: Seasonal variability of carbon dioxide in the rivers and lagoons of Ivory Coast (West Africa), Estuar. Coast., 32, 246260, https://doi.org/10.1007/s12237-008-9121-0, 2009.

Koné, Y. J. M., Abril, G., Delille, B., and Borges, A. V.: Seasonal variability of methane in the rivers and lagoons of Ivory Coast (West Africa), Biogeochemistry, 100, 21-37, https://doi.org/10.1007/s10533-009-9402-0, 2010.

Koroleff, F.: Determinationo of silicon, in: Methods of seawater analysis, edited by: Grasshoff, K., Ehrhardt, M., and Kremling, K., Verlag Chemie, Weinheim/Deerfield Beach, 174-187, 1983.

Kummu, M., Lu, X. X., Wang, J. J., and Varis, O.: Basinwide sediment trapping efficiency of emerging reser- 
voirs along the Mekong, Geomorphology, 119, 181-197, https://doi.org/10.1016/J.Geomorph.2010.03.018, 2010.

Lauri, H., de Moel, H., Ward, P. J., Räsänen, T. A., Keskinen, M., and Kummu, M.: Future changes in Mekong River hydrology: impact of climate change and reservoir operation on discharge, Hydrol. Earth Syst. Sci., 16, 4603-4619, https://doi.org/10.5194/hess-16-4603-2012, 2012.

Laruelle, G. G., Dürr, H. H., Slomp, C. P., and Borges, A. V.: Evaluation of sinks and sources of $\mathrm{CO}_{2}$ in the global coastal ocean using a spatially-explicit typology of estuaries and continental shelves, Geophys. Res. Lett., 37, L15607, https://doi.org/10.1029/2010g1043691, 2010.

Laruelle, G. G., Dürr, H. H., Lauerwald, R., Hartmann, J., Slomp, C. P., Goossens, N., and Regnier, P. A. G.: Global multi-scale segmentation of continental and coastal waters from the watersheds to the continental margins, Hydrol. Earth Syst. Sci., 17, 2029-2051, https://doi.org/10.5194/hess-17-2029-2013, 2013.

Le, T. P. Q., Marchand, C., Ho, C. T., Duong, T. T., Nguyen, H. T. M., XiXi, L., Vu, D. A., Doan, P. K., and Le, N. D.: $\mathrm{CO}_{2}$ partial pressure and $\mathrm{CO}_{2}$ emissions from the lower Red River (Vietnam), Biogeosciences Discuss., https://doi.org/10.5194/bg2017-505, in review, 2017.

Lefèvre, N., Flores Montes, M., Gaspar, F. L., Rocha, C., Jiang, S., De Araújo, M. C., and Ibánhez, J. S. P.: Net Heterotrophy in the Amazon Continental Shelf Changes Rapidly to a Sink of $\mathrm{CO}_{2}$ in the Outer Amazon Plume, Front. Mar. Sci., 4, 278, https://doi.org/10.3389/fmars.2017.00278, 2017.

Le Quéré, C., Andrew, R. M., Canadell, J. G., Sitch, S., Korsbakken, J. I., Peters, G. P., Manning, A. C., Boden, T. A., Tans, P. P., Houghton, R. A., Keeling, R. F., Alin, S., Andrews, O. D., Anthoni, P., Barbero, L., Bopp, L., Chevallier, F., Chini, L. P., Ciais, P., Currie, K., Delire, C., Doney, S. C., Friedlingstein, P., Gkritzalis, T., Harris, I., Hauck, J., Haverd, V., Hoppema, M., Klein Goldewijk, K., Jain, A. K., Kato, E., Körtzinger, A., Landschützer, P., Lefèvre, N., Lenton, A., Lienert, S., Lombardozzi, D., Melton, J. R., Metzl, N., Millero, F., Monteiro, P. M. S., Munro, D. R., Nabel, J. E. M. S., Nakaoka, S.-I., O'Brien, K., Olsen, A., Omar, A. M., Ono, T., Pierrot, D., Poulter, B., Rödenbeck, C., Salisbury, J., Schuster, U., Schwinger, J., Séférian, R., Skjelvan, I., Stocker, B. D., Sutton, A. J., Takahashi, T., Tian, H., Tilbrook, B., van der Laan-Luijkx, I. T., van der Werf, G. R., Viovy, N., Walker, A. P., Wiltshire, A. J., and Zaehle, S.: Global Carbon Budget 2016, Earth Syst. Sci. Data, 8, 605-649, https://doi.org/10.5194/essd-8-605-2016, 2016.

Li, S. and Bush, R. T.: Changing fluxes of carbon and other solutes from the Mekong River, Sci. Rep., 5, 16005, https://doi.org/10.1038/srep16005, 2015.

Li, S. Y., Lu, X. X., and Bush, R. T.: $\mathrm{CO}_{2}$ partial pressure and $\mathrm{CO}_{2}$ emission in the Lower Mekong River, J. Hydrol., 504, 40-56, https://doi.org/10.1016/j.jhydrol.2013.09.024, 2013.

Li, S. Y., Lu, X. X., and Bush, R. T.: Chemical weathering and $\mathrm{CO}_{2}$ consumption in the Lower Mekong River, Sci. Total Environ., 472, 162-177, https://doi.org/10.1016/j.scitotenv.2013.11.027, 2014.

Liu, J. P., DeMaster, D. J., Nguyen, T. T., Saito, Y., Nguyen, V. L., Ta, T. K. O., and Li, X.: Stratigraphic formation of the Mekong River Delta and its recent shoreline changes, Oceanography 30, 72-83, https://doi.org/10.5670/oceanog.2017.316, 2017.
Liu, K.-K., Chao, S.-Y., Shaw, P.-T., Gong, G.-C., Chen, C.C., and Tang, T. Y.: Monsoon-forced chlorophyll distribution and primary production in the South China Sea: observations and a numerical study, Deep-Sea Res. Pt. I, 49, 1387-1412, https://doi.org/10.1016/S0967-0637(02)00035-3, 2002.

Liu, Z. H., Wolfgang, D., and Wang, H. J.: A new direction in effective accounting for the atmospheric $\mathrm{CO}_{2}$ budget: considering the combined action of carbonate dissolution, the global water cycle and photosynthetic uptake of DIC by aquatic organisms. Earth Sci. Rev. 99, 162-172, https://doi.org/10.1016/j.earscirev.2010.03.001, 2010.

Loisel, H., Vantrepotte, V., Ouillon, S., Ngoc, D. D., Herrmann, M., Tran, V., Mériaux, X., Dessailly, D., Jamet, C., Duhaut, T., Nguyen, H. H., and Nguyen, T. V.: Assessment and analysis of the chlorophyll-a concentration variability over the Vietnamese coastal waters from the MERIS ocean color sensor (2002-2012), Remote Sens. Environ., 190, 217-232, https://doi.org/10.1016/j.rse.2016.12.016, 2017.

Lu, X. X., Li, S., Kummu, M., Padawangi, R., and Wang, J. J.: Observed changes in the water flow at Chiang Saen in the lower Mekong: Impacts of Chinese dams?, Quaternary Int., 336, 145157, https://doi.org/10.1016/j.quaint.2014.02.006, 2014.

Ludwig, W., Probst, J. L., and Kempe, S.: Predicting the oceanic input of organic carbon by continental erosion, Global Biogeochem. Cy., 10, 23-41, https://doi.org/10.1029/95GB02925, 1996.

Manaka, T., Otani, S., Inamura, A., Suzuki, A., Aung, T., Roachanakanan, R., Ishiwa, T., and Kawahata, H.: Chemical weathering and long-term $\mathrm{CO}_{2}$ consumption in the Ayeyarwady and Mekong river basins in the Himalayas, J. Geophys. Res.-Biogeo., 120, 1165-1175, https://doi.org/10.1002/2015JG002932, 2015.

Martin, E. E., Ingalls, A. E., Richey, J. E., Keil, R. G., Santos, G. M., Truxal, L. T., Alin, S. R., and Druffel, E. R. M.: Age of riverine carbon suggests rapid export of terrestrial primary production in tropics, Geophys. Res. Lett., 40, 5687-5691, https://doi.org/10.1002/2013GL057450, 2013.

Meybeck, M.: Carbon, nitrogen, and phosphorus transport by world rivers, Am. J. Sci., 282, 401-450, https://doi.org/10.2475/ajs.282.4.401, 1982.

Meybeck, M. and Carbonnel, J. P.: Chemical transport by the Mekong river, Nature, 255, 134-136, https://doi.org/10.1038/255134a0, 1975.

Middelburg, J. J., Nieuwenhuize, J., Iversen, N., Høgh, N., De Wilde, H., Helder, W., Seifert, R., and Christof, O.: Methane distribution in European tidal estuaries, Biogeochemistry, 59, 95119, https://doi.org/10.1023/A:1015515130419, 2002.

Milliman, J. D. and Farnsworth, K. L.: River Discharge to the Coastal Ocean: A Global Synthesis Cambridge University Press, 392 pp., 2011.

Mook, W. G. and Tan, T. C.: Stable carbon isotopes in rivers and estuaries, in: Biogeochemistry of major world rivers, edited by: Degens, E. T., Kempe, S., and Richey, J. E., SCOPE, Wiley, 245264, 1991.

Morris, A. W., Mantoura, R. F. C., Bale, A. J., and Howland, R. J. M.: Very low salinity regions of estuaries: important sites for chemical and biological reactions, Nature, 274, 678-680, https://doi.org/10.1038/274678a0, 1978. 
Muylaert, K. and Sabbe, K.: Spring phytoplankton assemblages in and around the maximum turbidity zone of the estuaries of the Elbe (Germany), the Schelde (Belgium/The Netherlands) and the Gironde (France), J. Mar. Syst., 22, 133-149, https://doi.org/10.1016/S0924-7963(99)00037-8, 1999.

Nguyen, A. D., Savenije, H. H. G., Pham, D. N., and Tang, D. T.: Using salt intrusion measurements to determine the freshwater discharge distribution over the branches of a multi-channel estuary: The Mekong Delta case, Estuar. Coast. Shelf S., 77, 433445, https://doi.org/10.1016/j.ecss.2007.10.010, 2008.

Nguyen, L.-D., Pham-Bach, V., Nguyen-Thanh, M., PhamThi, M.-T., and Hoang-Phi, P.: Change detection of land use and riverbank in Mekong Delta, Vietnam using time series remotely sensed data, J. Res. Ecol., 2, 370-374, https://doi.org/10.3969/j.issn.1674-764x.2011.04.011, 2011.

Piman, T., Lennaerts, T., and Southalack, P.: Assessment of hydrological changes in the lower Mekong Basin from basinwide development scenarios, Hydrol. Process., 27, 2115-2125, https://doi.org/10.1002/hyp.9764, 2013.

Piman, T., Cochrane, T. A., and Arias, M. E.: Effect of proposed large dams on water flows and hydropower production in the Sekong, Sesan and Srepok rivers of the Mekong basin, River Res. Appl., 32, 2095-2108, https://doi.org/10.1002/rra.3045, 2016.

Qiu, F., Fang, W., and Fanf, G.: Seasonal-to-interannual variability of chlorophyll in centralwestern South China Sea extracted from SeaWiFS, Chin. J. Oceanol. Limn., 29, 18-25, https://doi.org/10.1007/s00343-011-9931-y, 2011.

Ragueneau, O., Lancelot, C., Egorov, V., Vervlimmeren, J., Cociasu, A., Déliat, G., Krastev, A., Daoud, N., Rousseau, V., Popovitchev, V., Brion, N., Popa, L., and Cauwet, G.: Biogeochemical transformations of inorganic nutrients in the mixing zone between the Danube River and the Northwestern Black Sea, Estuar. Coast. Shelf S., 54, 321-336, https://doi.org/10.1006/ecss.2000.0650, 2002.

Rao, G. D. and Sarma, V. V. S. S.: Variability in concentrations and fluxes of methane in the Indian estuaries, Estuar. Coast., 39, 1639-1650, https://doi.org/10.1007/s12237-016-0112-2, 2016.

Raymond, P. A. and Cole, J. J.: Gas exchange in rivers and estuaries: Choosing a gas transfer velocity, Estuaries, 24, 312-317, https://doi.org/10.2307/1352954, 2001.

Raymond, P. A., Hartmann, J., Lauerwald, R., Sobek, S., McDonald, C., Hoover, M., Butman, D., Striegl, R., Mayorga, E., Humborg, C., Kortelainen, P., Dürr, H., Meybeck, M., Ciais, P., and Guth, P.: Global carbon dioxide emissions from inland waters, Nature, 503, 355-359, https://doi.org/10.1038/nature12760, 2013.

Reynolds, C. S. and Descy, J.-P.: The production, biomass and structure of phytoplankton in large rivers, Archiv für Hydrobiologie, 10, 161-187, https://doi.org/10.1127/lr/10/1996/161, 1996.

Rhee, T. S., Kettle, A. J., and Andreae, M. O.: Methane and nitrous oxide emissions from the ocean: A reassessment using basin-wide observations in the Atlantic, J. Geophys. Res., 114, D12304, https://doi.org/10.1029/2008JD011662, 2009.

Rosentreter, J. A., Maher, D. T., Erler, D. V., Murray, R., and Eyre, B. D.: Seasonal and temporal $\mathrm{CO}_{2}$ dynamics in three tropical mangrove creeks - A revision of global mangrove $\mathrm{CO}_{2}$ emissions, Geochim. Cosmochim. Ac., 222, 729-745, https://doi.org/10.1016/j.gca.2017.11.026, 2018.
Sarma, V. V. S. S., Viswanadham, R., Rao, G. D., Prasad, V. R., Kumar, B. S. K., Naidu, S. A., Kumar, N. A., Rao, D. B., Sridevi, T., Krishna, M. S., Reddy, N. P. C., Sadhuram, Y., and Murty, T. V. R.: Carbon dioxide emissions from Indian monsoonal estuaries, Geophys. Res. Lett., 39, L03602, https://doi.org/10.1029/2011GL050709, 2012.

Smajgl, A., Toan, T. Q., Nhan, D. K., Ward, J., Trung, N. H., Tri, L. Q., Tri, V. P. D., and Vu, P. T.: Responding to rising sea levels in the Mekong Delta, Nat. Clim. Change, 5, 167-174, https://doi.org/10.1038/nclimate2469, 2015.

Smith, S. V. and Key, G. S.: Carbon dioxide and metabolism in marine environments, Limnol. Oceanogr., 20, 493-495, https://doi.org/10.4319/lo.1975.20.3.0493, 1975.

Stanley, E. H., Casson, N. J., Christel, S. T., Crawford, J. T., Loken, L. C., and Oliver, S. K.: The ecology of methane in streams and rivers: patterns, controls, and global significance, Ecol. Monogr., 86, 146-171, https://doi.org/10.1890/15-1027, 2016.

Takagi, H., Tsurudome, C., Thao, N. D., Anh, L. T., Ty, T. V., and Tri, V. P. D.: Ocean tide modelling for urban flood risk assessment in the Mekong Delta, Hydrol. Res. Lett., 10, 21-26, https://doi.org/10.3178/hrl.10.21, 2016.

Testa, J. M., Kemp, W. M., Hopkinson, C. S., and Smith, S. V.: Ecosystem Metabolism, in: Estuarine Ecology, 2nd Edn., edited by: Day, J. W., Crump, B. C., Kemp, W. M., and YáñezArancibia, A., John Wiley \& Sons, Inc., Hoboken, NJ, USA, https://doi.org/10.1002/9781118412787.ch15, 2012.

Tong, P. H. S., Auda, Y., Populus, J., Aizpuru, M., Al Habshi, A., and Blasco, F.: Assessment from space of mangroves evolution in the Mekong Delta, in relation to extensive shrimp farming, Int. J. Remote Sens., 25, 4795-4812, https://doi.org/10.1080/01431160412331270858, 2010.

Tseng, H.-C., Chen, C.-T. A., Borges, A. V., Lai, C.-M., DelValls, T. A., and Chang, Y.-C.: Methane in the South China Sea and the Western Philippine Sea, Cont. Shelf Res., 135, 23-34, https://doi.org/10.1016/j.csr.2017.01.005, 2017.

Upstill-Goddard, R. C. and Barnes, J.: Methane emissions from UK estuaries: re-evaluating the estuarine source of tropospheric methane from Europe. Mar. Chem., 180, 14-23, https://doi.org/10.1016/j.marchem.2016.01.010, 2016.

Upstill-Goddard, R. C., Barnes, J., Frost, T., Punshon, S., and Owens, N. J. P.: Methane in the Southern North Sea: low salinity inputs, estuarine removal and atmospheric flux. Global Biogeochem. Cy., 14, 1205-1217, https://doi.org/10.1029/1999GB001236, 2000.

Varis, O., Kummu, M., and Salmivaara, A.: Ten major river basins in monsoon Asia-Pacific: an assessment of vulnerability, Appl. Geogr., 32, 441-454, https://doi.org/10.1016/j.apgeog.2011.05.003, 2012.

Västilä, K., Kummu, M., Sangmanee, C., and Chinvanno, S.: Modelling climate change impacts on the flood pulse in the Lower Mekong floodplains, J. Water Climate Change, 1, 67-86, https://doi.org/10.2166/wcc.2010.008, 2010.

Wang, J. J., Lu, X. X., and Kummu, M.: Sediment loads estimate in the lower Mekong River, River Res. Appl., 27, 22-46, https://doi.org/10.1002/rra.1337, 2011.

Wanninkhof, R.: Relationship between wind speed and gas exchange over the ocean, J. Geophys. Res., 97, 7373-7382, https://doi.org/10.1029/92JC00188, 1992. 
Weiss, R. F.: Carbon dioxide in water and seawater: the solubility of a non-ideal gas, Mar. Chem., 2, 203-215, https://doi.org/10.1016/0304-4203(74)90015-2, 1974.

Weiss, R. F.: Determinations of carbon dioxide and methane by dual catalyst flame ionization chromatography and nitrous oxide by electron capture chromatography, J. Chromatogr. Sci., 19, 611616, https://doi.org/10.1093/chromsci/19.12.611, 1981.

Weiss, R. F. and Price, B. A.: Nitrous oxide solubility in water and seawater, Mar. Chem., 8, 347-359, 1980.

Whitton, B. A.: River Ecology - Studies in Ecology, Blackwell Scientific Publications, Oxford, London, Edinburgh, Melbourne, 725 pp., 1975.

Yamamoto, S., Alcauskas, J. B., and Crozier, T. E.: Solubility of methane in distilled water and seawater, J. Chem. Eng. Data, 21, 78-80, https://doi.org/10.1021/je60068a029, 1976.
Zhai, W., Dai, M., and Guo, X.: Carbonate system and $\mathrm{CO}_{2}$ degassing fluxes in the inner estuary of Changjiang (Yangtze) River, China, Mar. Chem., 107, 342-356, https://doi.org/10.1016/j.marchem.2007.02.011, 2007.

Zhang, G., Zhang, J., Liu, S., Ren, J., Xu, J., and Zhang, F.: Methane in the Changjiang (Yangtze River) Estuary and its adjacent marine area: riverine input, sediment release and atmospheric fluxes, Biogeochemistry, 91, 71-84, https://doi.org/10.1007/s10533008-9259-7, 2008.

Zhou, H., Yin, X., Yang, Q., Wang, H., Wu, Z., and Bao, S.: Distribution, source and flux of methane in the western Pearl River Estuary and northern South China Sea, Mar. Chem., 117, 21-31, https://doi.org/10.1016/j.marchem.2009.07.011, 2009. 